\title{
MORPHOLOGICAL AND ECOGEOGRAPHIC STUDY OF THE DIVERSITY OF CASSAVA (Manihot esculenta Crantz) IN ECUADOR
}

\author{
Á. Monteros-Altamirano ${ }^{1 a}$, C. Tapia ${ }^{1 b}$, N. Paredes ${ }^{2 a}$, V. Alulema ${ }^{3}$, M. Tacán ${ }^{1 c}$,
} A. Roura ${ }^{1 \mathrm{~d}}$, L. Lima $^{2 b}$, M. Sørensen ${ }^{4 *}$

1a INIAP, Estación Experimental Santa Catalina, Panamericana sur km 1, Quito, Ecuador. E-mail: alvaro.monteros@iniap.gob.ec (orcid: 0000-0002-1271-3513)

${ }^{1 b}$ E-mail: cesar.tapia@iniap.gob.ec (orcid: 0000-0002-3815-4211)

1c E-mail: marcelo.tacan@iniap.gob.ec (orcid: 0000-0002-6775-1445)

1d E-mail: alberto.roura@iniap.gob.ec (orcid: 0000-0002-9311-9646)

${ }^{2 a}$ INIAP, Estación Experimental Central de la Amazonía, Vía Sacha San Carlos km 3 de la entrada a la Parker, Orellana, Ecuador. E-mail: nelly.paredes@iniap.gob.ec (orcid: 0000-0003-33208468)

${ }^{2 b}$ E-mail: luis.lima@iniap.gob.ec (orcid: 0000-0001-9352-1654)

${ }^{3}$ UCE (Universidad Central del Ecuador) - INBIOMED (Instituto de Investigación en Biomedicina), Hospital Docente de Calderón, Edificio CEGEMED, Quito, Ecuador. E-mail: vealulema@uce.edu.ec (orcid: 0000-0002-4617-5813)

4* Corresponding author; University of Copenhagen, Faculty of Science, Department of Plant and Environmental Sciences, Sobi/Plen-KU, Thorvaldsensvej 40, 3., DK-1871 Frederiksberg C. Denmark. E-mail: ms@plen.ku.dk (orcid: 0000-0001-6921-5366)

\begin{abstract}
Cassava (Manihot esculenta Crantz) is a crop of nutritional and economic importance worldwide, cultivated in more than 100 tropical and subtropical countries including Ecuador, traditionally cultivated in its three continental regions: the Amazon, the Coast and in the valleys of the Sierra. The purpose of this study was to characterize 195 accessions from INIAP's Ecuadorian cassava collection through 1) morphological characterization with qualitative and quantitative descriptors; and 2) ecogeographic characterization to know the climatic, geophysical and edaphic conditions in which cassava grows and which environments are frequent or marginal for its cultivation. For the morphological characterization, 27 morphological descriptors were used (18 qualitative and nine quantitative), and for the ecogeographic characterization, 55 variables (41 climatic, two geophysical and 12 edaphic). As a result, four morphological groups and three ecogeographic groups were identified. In the research, morphological variability was evidenced, mainly in descriptors related to the leaf, stems and inflorescences. In addition, it was possible to identify accessions that can adapt to extreme conditions of drought and poor soils, which could be used for improvement.
\end{abstract}




\section{KEYWORDS}

Variability, adaptation, GIS

\section{INTRODUCTION}

Cassava (Manihot esculenta Crantz) is an important food and economical crop worldwide, grown in more than 100 tropical and subtropical countries [1-3]. In developing countries, cassava is usually cultivated by subsistence farmers since it presents easy propagation systems, high tolerance to abiotic factors such as drought and biotic factors such as insects and viruses; and, a low nutrient demand, producing reasonably well in critical climatic and soil conditions [4-7]. In South America, the highest production is in Brazil, with 17,497,115 metric tons in 2019, while Ecuador occupies the eighth place; however, cassava is the fourth temporary crop with the largest surface area at the national level, 13,601 hectares and a production of 69,863 $\mathrm{m}$ tons [8]. Cassava has traditionally been cultivated in the Amazon region, followed by the Coast and valleys of the Sierra [9]. Amazonian nationalities recognize around 200 types of cassava, classifying them as bitter and sweet [10]. In the province of Manabí (Coast Region), more than self-consumption, it also generates economic income through the commercialization of fresh and/or processed cassava as flour [11].

Morphological characterization has been used for several purposes, including identifying duplicates, studies of variation, and correlation with characteristics of agronomic importance $[12,13]$. In addition, morphological traits are helpful for preliminary assessment (pre-breeding) because they offer a quick and easy approach to assessing the extent of diversity. The registration of a sample or variety's characteristics is based on a list of morphological and agronomic descriptors, i.e. essential and useful characteristics in the description of the sample. These descriptors must be readily observable, have high discriminant action and low environmental influence [14-17]. For example, the EMBRAPA-Brazil Corporation established 75 morphological descriptors for cassava [18]; these descriptors have allowed morphologically validating 26 ethno-varieties in Peru [19], 116 elite genotypes collected in Benin, Africa [20], 47 traditional varieties in Brazil [21], 159 accessions conserved in the field in Côte d'Ivoire, Africa [22] and in Mexico 40 accessions were characterized from a germplasm bank [23].

On the other hand, ecogeographic characterization is a process that allows comparing the diversity of a species or group of species, allowing the completion of the morphological and genotypic information using the environmental information from the germplasm collection site [24,25]. For example, Mezghani et al. [26] used ecogeographic information to characterize wild relatives of carrot (Daucus L.) subjected to abiotic stresses of interest in crop improvement and to assess their ex-situ and in-situ conservation status in Tunisia. Likewise, it can be used to understand environmental conditions and associated biotic and abiotic factors to which plant species have adapted, as was the study carried out in teosinte [27]. At present, programs have been developed that use geographic information systems, such as CAPFITOGEN [28]. This program uses ecogeographic analysis tools to carry out several ecogeographic crop studies in Ecuador, e.g. maize (Zea mays L.) [29], capulin 
(Prunus serotina Ehrh. subsp. capuli (Cav. ex Spreng.) McVaugh) [30] and ulluco (Ullucus tuberosus Caldas) [31].

The purpose of this study was to characterize 195 accessions from INIAP's Ecuadorian cassava collection through 1) morphological characterization with qualitative and quantitative descriptors; and 2) ecogeographic characterization to know the climatic, geophysical and soil conditions where cassava grows, and with environmental cultivation conditions that are either frequent or marginal.

\section{MATERIALS AND METHODS}

\section{Cassava collection}

The cassava collection encompasses 195 accessions (96 accessions collected and acquired more than two decades ago and 99 accessions collected from 2012 and 2013). The collection of landraces was carried out to representative cropping areas throughout Ecuador. Collections were performed according to standard protocols established by the National Department of Plant Genetic Resources of the National Institute for Agricultural Research INIAP, of Ecuador [32]. As only cultivated materials were collected, not special permit from the Ministry of Environment and Water was necessary for collection, which is necessary only for wild species. Passport data included information on the collector, the provider, geographical location: latitude, longitude, altitude, ecological information, soil, and uses. We collected cuttings from each accession, then watered, labelled and stored them in plastic bags until they arrived at the Experimental Station fields for planting.

\section{Morphological characterization}

The 195 accessions of the Ecuadorian collection were planted at the Central Amazon Experimental Station of INIAP, located at Via Sacha-San Carlos at $250 \mathrm{~m}$ a.s.1., with an average temperature of $24^{\circ} \mathrm{C}$ and average precipitation of $3100 \mathrm{~mm}$. The cuttings were previously planted in plastic grow bags with the substrate (black soil, compost and coffee husks) where they remained for a period of 4 to 8 weeks, and then five plants per accession were transplanted into the field at a distance of $1 \mathrm{~m}$ between plants and $2 \mathrm{~m}$ between accessions. Pruning was performed after 30 days to leave a single shoot for characterization.

The collection was morphologically characterized by using 27 morphological descriptors (18 qualitative and nine quantitative) according to Fukuda and Guevara [18]. Quantitative descriptors were recorded based on the average value obtained from five random plants within each accession. Quantitative descriptors include the length of leaf lobe, the width of leaf lobe, the number of leaf lobes, the distance between leaf scars, plant height, height to first branching, total fresh weight of storage roots per plant, length of storage root, and the diameter of the storage root. The qualitative descriptors were the initial vigour of the plant, the colour of apical leaves, pubescence on apical leaves, shape of the central leaflet, petiole colour, leaf colour, colour of stem epidermis, flowering, colour of end branches of adult plant, plant earliness, the shape of the plant, root constrictions, texture of the root epidermis, the extent of the root peduncle, colour of the root cortex, colour of the root pulp (parenchyma), cortex, i.e. ease of peeling and shape of the root. 


\section{Ecogeographical Characterization}

As mentioned before, the 195 accessions studied were collected in the Coast and the Amazonia regions of Ecuador. Plains generally form the landscape in the Coast region, and the Amazonia is formed by hills that originate in the eastern part of the Andes and descend towards the Amazonian plains. Humidity percentages close to $100 \%$ are found in the Amazonia throughout the year and for the Coast region during the winter period. The annual mean temperature varies between 23 and $26^{\circ} \mathrm{C}$ in both regions. Precipitation in the Amazonia is continuous and intense throughout the year (3000 $\mathrm{mm}$ average), while on the Coast, the strong winter period is from February to May and mild winter period from September to November.

On the contrary, the dry months are July and August, and summer weather from December to January [33]. Moreover, soils on the Coast are usually flood plains that have accumulated fertile sediments from the highlands. As a result, the soils of the Ecuadorian Amazon have great acidity [34].

Using the ECOGEO tool of the CAPFITOGEN program [28], the ecogeographic characterization was carried out using the 55 ecogeographic variables (Supplementary Table 1). First applying ECOGEO, a grid resolution of $5 \times 5 \mathrm{~km}$ (2.5 arc-minutes) was chosen to extract the information, and subsequently using the INFOSTAT program (version 2018) to edit the recorded data for analysis [35].

\section{Ecogeographical Land Characterization Map}

To define the environments in which each cassava landrace is grown, a specific ecogeographic land characterization map for cassava landraces was developed for Ecuador. Using the CAPFITOGEN program and the ELC Map tool [28], the first step was creating the map with a grid cell size of $5 \mathrm{~km}$ by $5 \mathrm{~km}$ (2.5 arc-minutes) covering the Coast region and the Amazon of Ecuador. Next, the centroid of each cell was calculated, and data were extracted from 55 ecogeographic variables (41 climatic, two geophysical, 12 edaphic) compiled as GIS layers. Table 1 presents the data sources, formats, and scales or resolution of thematic layers. The variables from each module were then submitted to correlation analysis, principal components and random forest to identify redundant information. For each variable, the number of significant correlations was computed. According to this number, variables were then arranged in ascending order, and those with fewer than the median number of significant correlations were selected for further consideration. On the other hand, four Ecuadorian breeding research experts were consulted about the environmental conditions affecting the cultivation of cassava landraces. Combining the different climatic, edaphic, and geophysical clusters provided the ecogeographic categories used to generate the ELC map.

\section{Statistical analysis}

The morphological and ecogeographic characterization data was examined using the INFOSTAT program version 2018 [35]. All the quantitative variables recorded were 
subjected to descriptive statistical analysis (minimum, maximum, average, standard deviation and coefficient of variation) to appreciate the variability of each trait among the cassava varieties. To identify the variables with more significant variation, the $\mathrm{CV}$ was calculated for quantitative variables and the index of deviation from the mode (DM) proposed by [36] for qualitative variables. The formula used to calculate DM was 1$\left(\left(\sum(\mathrm{i}=1)^{\wedge} \mathrm{k}\right.\right.$ w. number of categories, and $\mathrm{N}$ is the number of cases. Thus, DM ranges between 0 (no variation) when all the cases fall in a single category and 1 (maximum variation) when the cases are distributed evenly across the categories. For the multivariate analysis, Gower distance and Ward's algorithm were applied to determine the correlation among accessions [35].

\section{RESULTS}

\section{Morphological characterization}

In this study, the existence of morphological variability within the 195 accessions evaluated was evidenced.

\section{Quantitative descriptors}

Table 1 summarizes the values for nine quantitative descriptors. The range of the values produced for the total fresh weight of the storage roots per plant was from $0.84 \mathrm{~kg}$ to 22.00 $\mathrm{kg}$, for the height at the first branch from $10.00 \mathrm{~cm}$ to $233.33 \mathrm{~cm}$. The coefficients of variation ranged from $13.13 \%$ (length of the leaf lobe) to $61.22 \%$ (total fresh weight of storage roots per plant). Based on the nine quantitative traits, seven had high coefficients of variation $(\mathrm{CV}>15 \%)$. Only two characters have low coefficients of variation; these are the number of leaf lobes (14.18\%) and the length of the leaf lobe (13.13\%).

Table 1. Morphological variability with quantitative characters in cassava collection from the Ecuadorian Andes.

\begin{tabular}{lrrrc}
\hline \multicolumn{1}{c}{ Variables } & CV & Min & Max & Mean \pm SD \\
\hline Total fresh weight of storage roots per plant, kg & 61.22 & 0.84 & 22.00 & $5.85 \pm 3.58$ \\
Height to first branching, cm & 42.67 & 10.00 & 233.33 & $96.87 \pm 41.33$ \\
Length of storage root, cm & 27.04 & 23.20 & 84.00 & $44.97 \pm 12.16$ \\
Plant height, cm & 24.63 & 83.33 & 393.33 & $251.03 \pm 61.82$ \\
Diameter of storage root, cm & 24.26 & 3.00 & 17.20 & $9.31 \pm 2.30$ \\
Distance between leaf scars, cm & 19.48 & 0.28 & 0.70 & $0.49 \pm 0.10$ \\
Width of leaf lobe, cm & 16.19 & 2.48 & 8.57 & $5.61 \pm 0.91$ \\
Number of leaf lobes & 14.18 & 5.00 & 11.00 & $7.76 \pm 1.10$ \\
Length of leaf lobe, cm & 13.13 & 11.95 & 29.90 & $20.37 \pm 2.67$ \\
\hline
\end{tabular}

\section{Qualitative descriptors}

Table 2 includes the index of deviation from the mode values, where the most frequent character in the collection is observed for each variable. Most of the descriptors presented deviation indices above 0.25 . The descriptors that presented the most significant variation were Pubescence in apical leaves (0.96), the Colour of apical leaves (0.88), Extension of 
the root peduncle (0.86). In the descriptors with more significant variability, most of the accessions presented absence of the apical leaf pubescence, light green apical leaves and short root peduncle.

Table 2. Morphological variability with qualitative characters in cassava collection from the Ecuadorian Andes.

\begin{tabular}{lcc}
\hline \multicolumn{1}{c}{ Variables } & $\begin{array}{c}\text { Index of deviation } \\
\text { from the mode }\end{array}$ & Mode \\
\hline Pubescence on apical leaves & 0.96 & Absent \\
Colour of apical leaves & 0.88 & Light green \\
Extent of root peduncle & 0.86 & Short \\
Colour of root cortex & 0.76 & Purple \\
Initial vigour of the plant & 0.70 & Good \\
Petiole colour & 0.67 & Red with green \\
Colour of end branches of adult plant & 0.62 & Dark green \\
Plant earliness & 0.62 & Intermediate \\
Shape of central leaflet & 0.56 & Elliptical lanceolate \\
Colour of stem epidermis & 0.53 & Dark green \\
Flowering & 0.52 & Present \\
Texture of root epidermis & 0.45 & Rough \\
Shape of root & 0.43 & Conical-cylindrical \\
Root constrictions & 0.38 & Absent \\
Colour of root pulp (parenchyma) & 0.26 & White \\
Cortex: ease of peeling & 0.25 & Easy \\
Shape of plant & 0.11 & Umbrella \\
Leaf colour & 0.07 & Dark green \\
\hline
\end{tabular}

\section{Multivariate analysis: Clusters description}

Four different groups were obtained based on the multivariate grouping analysis with quantitative and qualitative morphological data (Fig. 1). The genetic relationships between the 195 accessions evaluated determine a tendency to group according to their origin. Group 1 represented 26 accessions, of which 22 accessions $(84.62 \%)$ are from the Coast and four accessions (15.38\%) from the Amazon. Group 2 comprises 54 accessions; 45 accessions $(83.33 \%)$ are from the Coast and nine accessions $(16.67 \%)$ from the Amazon. In general, group 1 and 2 are represented by the Amazon and Costa regions. Group 3 contain 33 accessions, of which 25 accessions $(75.76 \%)$ are from the Coast region, seven accessions (21.21\%) from the Amazon region and one accession $(3.03 \%)$ from the Sierra. Group 4 includes 82 accessions, of which 67 accessions $(81.71 \%)$ correspond to the Amazon region, 14 accessions (17.07\%) from the Coast and one accession from the Sierra with $1.22 \%$. In general, groups 3 and 4 are represented by the three regions: Costa, Sierra and Amazonia. It is important to note that the province of Tungurahua, located in the Sierra Region, includes two accessions, one in Group 3 and the second in Group 4. However, when reviewing the passport data, these two accessions were collected in Rio Verde located in the eastern Andean mountain slopes bordering the Amazonian Pastaza province. 


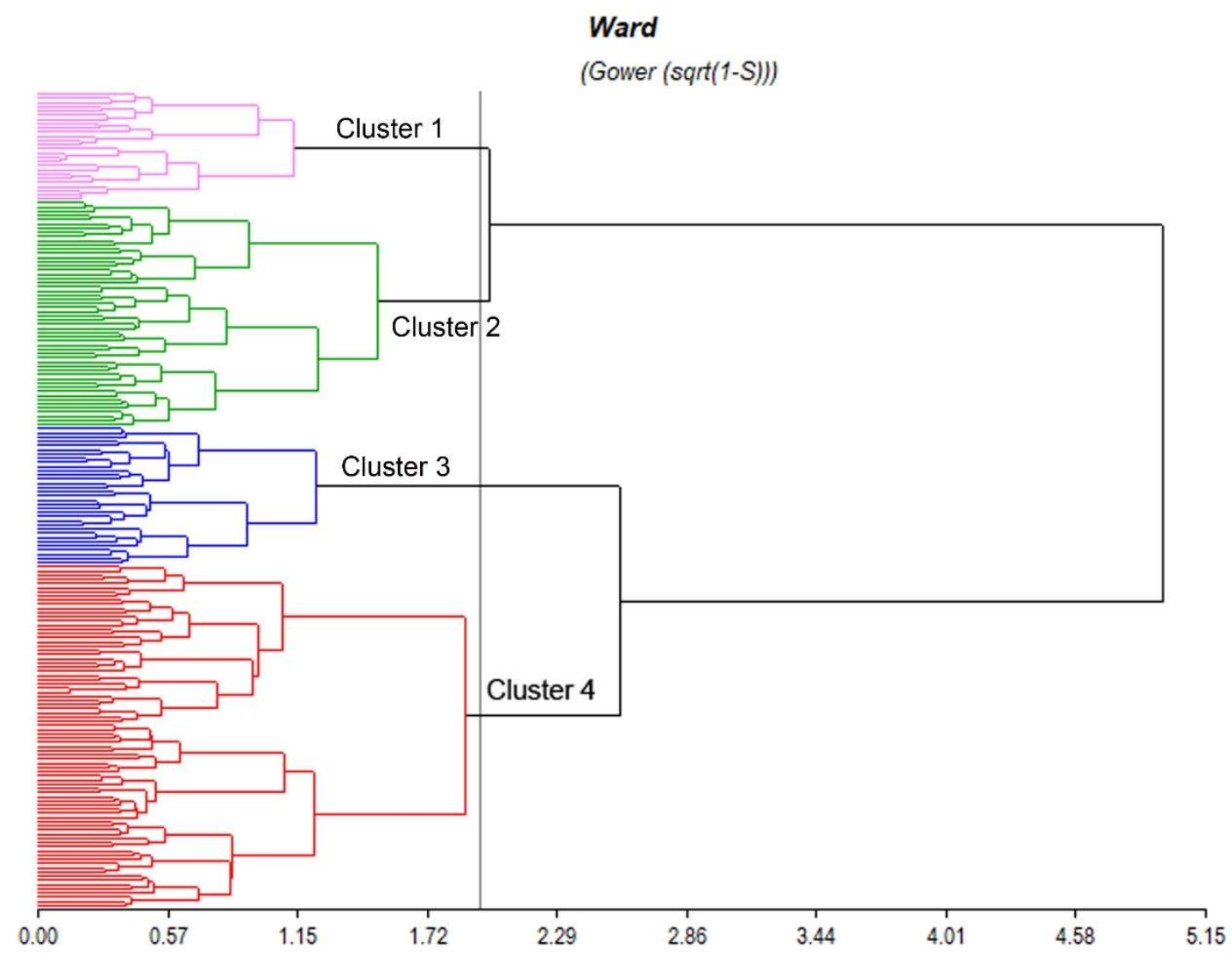

Figure 1. Dendrogram of 195 accessions of Manihot esculenta, indicating four groups of accessions based on quantitative morphological data using according to Ward's method and Gower's distance.

\section{Group 1}

Group 1 amounts to 26 accessions (Appendix 1) from four coastal provinces (Esmeraldas, Guayas, Manabí and Santo Domingo de Los Tsáchilas) and three Amazon provinces (Francisco de Orellana, Napo and Pastaza). The majority originates from the Coast region $(84.62 \%)$, and within the region, the accessions are mainly from the province of Manabí $(69.23 \%)$.

The quantitative morphological variables with the most significant variation for this group were mean root weight (CV 60.78\%), the height of the first branch (CV 42.84\%), plant height (CV 31.01\%), length root (CV 20.75\%) and internode distance (CV 20.69\%). Thus, the accessions of this group present three characters with wide ranges, plant height between $98.00 \mathrm{~cm}$ and $350.00 \mathrm{~cm}$, height at the first branch between $10.00 \mathrm{~cm}$ to $210.00 \mathrm{~cm}$, and root length registered 29, $92 \mathrm{~cm}$ to $58.00 \mathrm{~cm}$ (Appendix 2).

Regarding the qualitative characteristics, group 1 (Appendix 3), the majority of individuals presented i. good initial vigour of the plant; ii. presence of pubescence of the apical leaf; iii. 
leaves with lanceolate central lobe shape; iv. the petiole colour red with a bit of green; v. dark green stem epidermis; vi. no flowering; vii. dark green terminal branches; viii. intermediate earliness; ix. short root peduncle; x. purple root bark, and xi. white root pulp.

\section{Group 2.}

Group 2 presents 54 accessions (Appendix 1), these were collected in the coastal regions (Esmeraldas, Guayas, Manabí and Santo Domingo de Los Tsáchilas provinces) and Amazonia (Francisco de Orellana, Napo, Pastaza and Zamora Chinchipe provinces). Most of them belong to In the Cost region (84.62\%), where the accessions collected in the Manabí province $(61.11 \%)$ predominate.

The quantitative morphological variables with the greatest variation for this group were: Mean root weight (CV 68.76\%), height of the first branch (CV 36.92\%), root length (CV $28.56 \%$ ), plant height (CV 24.59\%), and root diameter (CV 24.14\%). The accessions of this group present, like group 3, three characters with wide ranges, plant height between 127.00 $\mathrm{cm}$ and $330.00 \mathrm{~cm}$, height at the first branch between $30.00 \mathrm{~cm}$ to $200.00 \mathrm{~cm}$, and root length recorded $23.20 \mathrm{~cm}$ to $82.33 \mathrm{~cm}$ (Appendix 2).

Regarding the qualitative characteristics, group 2 (Appendix 3) presented i. good and regular initial vigour of the plant; ii. presence of pubescence of the apical leaf; iii. leaves with elliptical-lanceolate central lobe shape; iv. petiole colour red with a little green; v. dark green epidermis of the stem; vi. presence of flowering; vii. dark green terminal branches; viii. late maturing; ix. short root peduncle; x. purple root bark, and xi. white root pulp.

\section{Group 3.}

This group 3 presents 33 accessions (Appendix 1) collected in four provinces of the Coast (Guayas, Los Ríos, Manabí and Santo Domingo de Los Tsáchilas), five provinces of the Amazon (Francisco de Orellana, Napo, Sucumbíos, Pastaza and Zamora Chinchipe ) and Sierra (Tungurahua). Most accessions in this group were collected in the Coast region $(75.76 \%)$ and mainly originate in the province of Manabí (60.61\%).

The quantitative morphological variables with the most significant variation for this group were: Mean root weight (CV 56.05\%), the height of the first branch (CV 43.08\%), plant height (CV 22.94\%), and root diameter (CV 22.23\%). Thus the accessions of this group have a wide range of plant height between $83 \mathrm{~cm}$ and $350 \mathrm{~cm}$, the height at the first branch between $24.67 \mathrm{~cm}$ to $166.67 \mathrm{~cm}$, root length registered $35.00 \mathrm{~cm}$ to $62.67 \mathrm{~cm}$, and the mean root weight between $1.00 \mathrm{~kg}$ to $22.00 \mathrm{~kg}$ (Appendix 2).

Regarding the qualitative morphological characteristics, group 3 (Appendix 3) presents $i$. good and regular initial vigour of the plant; ii. pubescence of the apical leaf; iii. leaves with an elliptic-lanceolate central lobe; iv. red coloured petiole with a bit of green; v. light green stem epidermis; vi. presence of flowering; vii. light green terminal branches, viii. intermediate earliness; ix. absent root peduncle, x. pink root bark, and xi. white root pulp.

\section{Group 4.}

Group 4 presents the highest number of accessions of all groups with 82 accessions (Appendix 1) collected in eleven Ecuadorian provinces Esmeraldas, Guayas, Manabí and Santo Domingo de Los Tsáchilas in the Cost region; Francisco de Orellana, Morona Santiago , Napo, Sucumbíos, Pastaza and Zamora Chinchipe in the Amazon region; and Tungurahua in the Sierra region. Most of the accessions were collected in the Amazon 
region $(81.71 \%)$, the majority in the province of Sucumbíos $(21.95 \%)$, followed by the provinces of Napo, Francisco de Orellana and Pastaza, each with 15.85\%.

The quantitative morphological variables with the most significant variation for this group were: total fresh weight of storage roots per plant (CV 52.32\%), height to first branching (CV 44.99\%), length of storage root (CV 27.20\%), diameter of storage root (CV 23.86\%), plant height (CV 22.63\%), and distance between leaf scars (CV 21.25\%). The accessions of this group present a wide range of plant height between $90 \mathrm{~cm}$ and $393 \mathrm{~cm}$, the height at the first branch between $20.00 \mathrm{~cm}$ to $233.33 \mathrm{~cm}$; root length registered $23.67 \mathrm{~cm}$ to $48.00 \mathrm{~cm}$, Leaf lobe length ranged from $11.95 \mathrm{~cm}$ to $29.90 \mathrm{~cm}$ and mean root weight between $1.00 \mathrm{~kg}$ to $18.47 \mathrm{~kg}$ (Appendix 2).

Regarding the qualitative characteristics of group 4 (Appendix 3), most of the accessions present i. an initial fair and reasonable plant vigour; ii. absence of pubescence of the apical leaf; iii. leaves with elliptical-lanceolate and lanceolate central lobe shape; iv. petiole colour red, red with little green and purple; v. stem epidermis dark green; vi. the presence of flowering; vii. terminal branches green with light, dark and purple hues; viii. intermediate earliness, ix. intermediate root peduncle, x. purple root bark; and, xi. white root pulp.

\section{Ecogeographic characterization}

\section{Distribution of the diversity of Ecuadorian cassava}

Seven life zones were identified (Humid Forest, Humid Forest, Very Dry Forest, Rain Forest, Dry Forest, Thorny Steppe and Thorny Mountain) where cassava diversity is growing in Ecuador, in a variation of altitude ranges and climatic conditions (Fig. 2). 


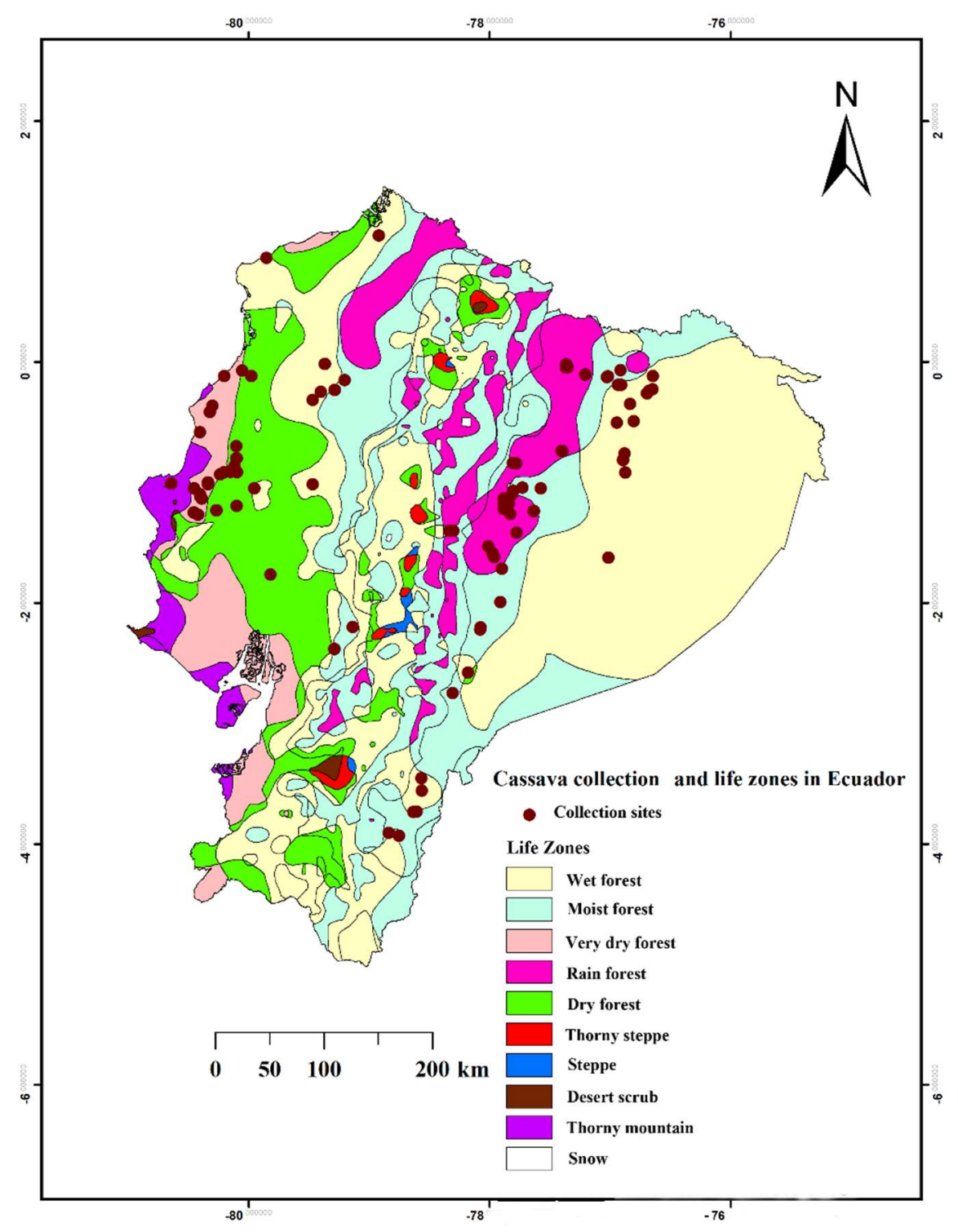

Figure 2. Distribution of 199 cassava accessions collected in Ecuador; seven life zones throughout Ecuador are coloured accordingly.

\section{Ecogeographic characterization map of the soil}

In order to define the areas in which cassava cultivation is adapted, a specific soil type characterization map was elaborated for the continental regions of Ecuador (Coast, Sierra foothills and Amazon). The ELC map was defined by 16 ecogeographic categories (Fig. 3) based on a combination of 41 bioclimatic variables, two geophysical and 12 edaphic. 


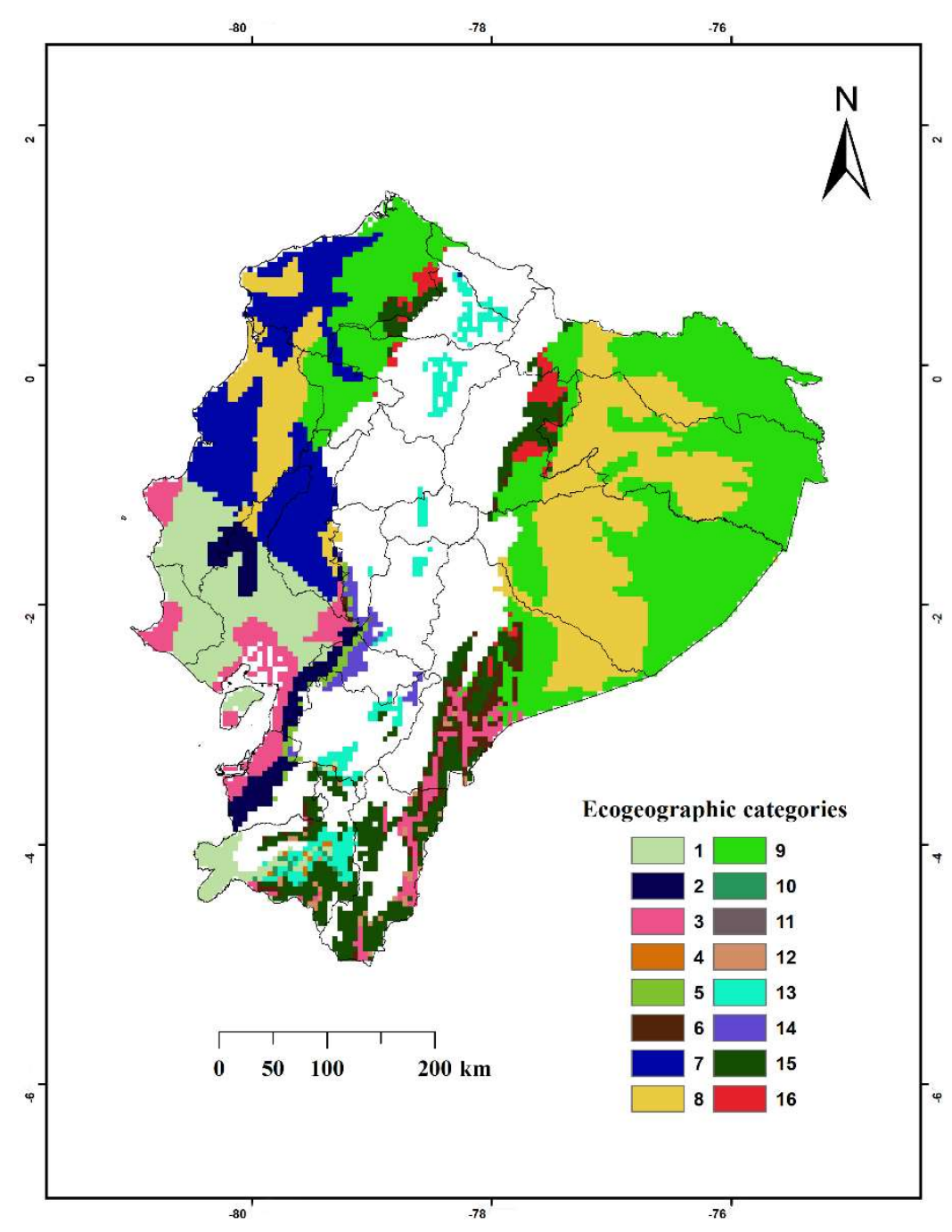

Figure 3. Map of specific ecogeographic characterization in continental Ecuador, where the local varieties of cassava are developed.

The most frequent ecogeographic categories were 8 (21\%) and category $9(31.6 \%)$, which add up to $52.6 \%$ of the Ecuadorian territory.

Category 8 presents the following characteristics: maximum temperature of the hottest month $\left(30.2^{\circ} \mathrm{C}\right)$, minimum temperature of the coldest month $\left(19.1^{\circ} \mathrm{C}\right)$. The highest precipitation was the month of May $(273 \mathrm{~mm})$, the lowest precipitation was in August (171 $\mathrm{mm}$ ), the months of January and March were those that registered the maximum temperature $29.5^{\circ} \mathrm{C}$, while the minimum temperatures corresponded to the months of July and August with $19.2^{\circ} \mathrm{C}$, and the altitude was $313 \mathrm{~m}$ a.s.l. The sand content in the soil was $19.6 \%$, and the soil $\mathrm{pH}$ was 5 .

In category 9 , the maximum temperature of the hottest month $\left(30.3^{\circ} \mathrm{C}\right)$ was recorded; the minimum temperature of the coldest month $\left(19.3^{\circ} \mathrm{C}\right)$, the highest precipitation was in May $(302 \mathrm{~mm})$, the precipitation in August was the lowest $(200 \mathrm{~mm})$. In January and March, the Maximum temperatures with $29.8^{\circ} \mathrm{C}$ and $29.7^{\circ} \mathrm{C}$, the minimum temperatures were July 
and August with $19.4^{\circ} \mathrm{C}$ and $19.3^{\circ} \mathrm{C}$. The altitude where these cassava accessions are developing is $321 \mathrm{~m}$ a.s.l. The sand content in the soil is (39.3\%) and the soil $\mathrm{pH}$ of 4.9 .

The climatic variables with the greatest variation were August average precipitation, $\mathrm{mm}$ $(\mathrm{CV}=101.75)$, October average precipitation, $\mathrm{mm}(\mathrm{CV}=99.89)$ and May average precipitation, $\mathrm{mm}(\mathrm{CV}=66.52)$. The quantitative edaphic variables with the greatest variation were: Gravel content in the subsoil, $\%(\mathrm{CV}=217.40)$, sand content in the subsoil, \% $(\mathrm{CV}=50.96)$ and sand content in the soil,\% $(\mathrm{CV}=41.64)$, (Table 3).

Table 3. Ecogeographic variability of quantitative traits in the Ecuador cassava collection.

\begin{tabular}{|c|c|c|c|c|}
\hline Variables & $\mathbf{C V}$ & Min & Max & Mean \pm SD \\
\hline Altitude, $\mathrm{m}$ a.s.l. & 78.59 & 5.00 & 1566.00 & $360.99 \pm 283.69$ \\
\hline Average annual temperature ${ }^{\circ} \mathrm{C}$ & 5.09 & 18.40 & 26.00 & $24.04 \pm 1.22$ \\
\hline Isothermal*, ${ }^{\circ} \mathrm{C}$ & 4.73 & 7.00 & 9.00 & $8.32 \pm 0.39$ \\
\hline Temperature seasonality**, ${ }^{\circ} \mathrm{C}$ & 26.08 & 31.70 & 92.60 & $57.11 \pm 14.89$ \\
\hline Maximum temperature for warmest month, ${ }^{\circ} \mathrm{C}$ & 4.30 & 24.10 & 31.90 & $29.92 \pm 1.29$ \\
\hline Minimum temperature for coldest month, ${ }^{\circ} \mathrm{C}$ & 6.64 & 12.90 & 21.80 & $18.35 \pm 1.22$ \\
\hline Annual temperature range $e^{* * *},{ }^{\circ} \mathrm{C}$ & 6.10 & 7.80 & 13.60 & $11.57 \pm 0.71$ \\
\hline $\begin{array}{l}\text { Average temperature for the coldest trimester (coldest three } \\
\text { months), }{ }^{\circ} \mathrm{C}\end{array}$ & 5.14 & 17.60 & 25.60 & $23.29 \pm 1.20$ \\
\hline $\begin{array}{l}\text { Average temperature for the quarter with most rainfall (three } \\
\text { rainiest months), }{ }^{\circ} \mathrm{C}\end{array}$ & 6.23 & 18.30 & 26.50 & $24.32 \pm 1.52$ \\
\hline $\begin{array}{l}\text { The average temperature for the hottest trimester (hottest three } \\
\text { months), }{ }^{\circ} \mathrm{C}\end{array}$ & 5.42 & 18.70 & 26.50 & $24.72 \pm 1.34$ \\
\hline Maximum temperature for January, ${ }^{\circ} \mathrm{C}$ & 4.54 & 23.00 & 31.00 & $29.08 \pm 1.32$ \\
\hline Maximum temperature for February, ${ }^{\circ} \mathrm{C}$ & 4.42 & 23.10 & 31.20 & $29.19 \pm 1.29$ \\
\hline Maximum temperature for March, ${ }^{\circ} \mathrm{C}$ & 5.04 & 23.20 & 31.50 & $29.39 \pm 1.48$ \\
\hline Maximum temperature for April, ${ }^{\circ} \mathrm{C}$ & 5.37 & 23.30 & 31.90 & $29.44 \pm 1.58$ \\
\hline Maximum temperature for May, ${ }^{\circ} \mathrm{C}$ & 4.82 & 23.10 & 31.00 & $28.83 \pm 1.39$ \\
\hline Maximum temperature for June, ${ }^{\circ} \mathrm{C}$ & 4.35 & 22.40 & 30.10 & $27.96 \pm 1.22$ \\
\hline Maximum temperature for July, ${ }^{\circ} \mathrm{C}$ & 4.47 & 21.90 & 29.90 & $27.76 \pm 1.24$ \\
\hline Minimum temperature for January, ${ }^{\circ} \mathrm{C}$ & 7.29 & 14.00 & 22.60 & $19.62 \pm 1.43$ \\
\hline Minimum temperature for February, ${ }^{\circ} \mathrm{C}$ & 7.65 & 14.10 & 22.80 & $19.71 \pm 1.51$ \\
\hline Minimum temperature for March, ${ }^{\circ} \mathrm{C}$ & 7.96 & 14.20 & 22.90 & $19.94 \pm 1.59$ \\
\hline Minimum temperature for April, ${ }^{\circ} \mathrm{C}$ & 7.70 & 14.20 & 23.00 & $19.86 \pm 1.53$ \\
\hline Minimum temperature for May, ${ }^{\circ} \mathrm{C}$ & 7.05 & 14.10 & 23.00 & $19.62 \pm 1.38$ \\
\hline \multicolumn{5}{|l|}{ Minimum temperature for June, ${ }^{\circ} \mathrm{C}$} \\
\hline Minimum temperature for July, ${ }^{\circ} \mathrm{C}$ & 7.16 & 13.30 & 22.50 & $19.11 \pm 1.37$ \\
\hline Minimum temperature for August, ${ }^{\circ} \mathrm{C}$ & 6.93 & 13.00 & 22.20 & $18.61 \pm 1.29$ \\
\hline Minimum temperature for September, ${ }^{\circ} \mathrm{C}$ & 6.67 & 12.90 & 22.10 & $18.35 \pm 1.22$ \\
\hline Minimum temperature for October, ${ }^{\circ} \mathrm{C}$ & 6.19 & 13.1 & 21.8 & $18.62 \pm 1.15$ \\
\hline Minimum temperature for November, ${ }^{\circ} \mathrm{C}$ & 6.21 & 13.60 & 22.00 & $18.91 \pm 1.17$ \\
\hline Minimum temperature for December, ${ }^{\circ} \mathrm{C}$ & 6.13 & 13.80 & 22.30 & $19.32 \pm 1.18$ \\
\hline January average temperature, ${ }^{\circ} \mathrm{C}$ & 5.48 & 18.50 & 26.20 & $24.32 \pm 1.33$ \\
\hline February average temperature, ${ }^{\circ} \mathrm{C}$ & 5.53 & 18.60 & 26.30 & $24.42 \pm 1.31$ \\
\hline March average temperature, ${ }^{\circ} \mathrm{C}$ & 6.13 & 18.70 & 26.60 & $24.64 \pm 1.51$ \\
\hline April average temperature, ${ }^{\circ} \mathrm{C}$ & 6.22 & 18.70 & 26.80 & $24.62 \pm 1.53$ \\
\hline May average temperature,${ }^{\circ} \mathrm{C}$ & 5.63 & 18.60 & 26.40 & $24.20 \pm 1.36$ \\
\hline June average temperature, ${ }^{\circ} \mathrm{C}$ & 5.40 & 17.80 & 26.00 & $23.50 \pm 1.27$ \\
\hline July average temperature, ${ }^{\circ} \mathrm{C}$ & 5.32 & 17.40 & 25.70 & $23.16 \pm 1.23$ \\
\hline August average temperature, ${ }^{\circ} \mathrm{C}$ & 4.90 & 17.80 & 25.70 & $23.41 \pm 1.15$ \\
\hline October average temperature, ${ }^{\circ} \mathrm{C}$ & 4.56 & 18.60 & 25.80 & $23.97 \pm 1.09$ \\
\hline December average temperature, ${ }^{\circ} \mathrm{C}$ & 4.76 & 18.70 & 26.10 & $24.31 \pm 1.16$ \\
\hline $\begin{array}{l}\text { Precipitation during the hottest quarter (the three hottest } \\
\text { months), mm }\end{array}$ & 40.58 & 193.00 & 1615.00 & $809.62 \pm 328.56$ \\
\hline Average precipitation for May, $\mathrm{mm}$ & 66.52 & 9.00 & 470.00 & $220.02 \pm 146.36$ \\
\hline Average precipitation for August, $\mathrm{mm}$ & 101.75 & 2.00 & 349.00 & $113.67 \pm 115.66$ \\
\hline Average precipitation for October, $\mathrm{mm}$ & 99.89 & 3.00 & 367.00 & $144.52 \pm 144.37$ \\
\hline Sand content in the soil, \% & 41.64 & 11.00 & 72.00 & $27.43 \pm 13.98$ \\
\hline Sand content in the subsoil, \% & 50.96 & 13.00 & 70.00 & $27.43 \pm 13.98$ \\
\hline Gravel content in the subsoil, \% & 217.40 & 0.00 & 49.00 & $6.03 \pm 13.11$ \\
\hline
\end{tabular}


* (Daytime mean temperature range / annual temperature range) * 100. ** Standard deviation * 100. *** Maximum temperature for warmest month. Minimum temperature for the coldest month.

For other qualitative edaphic variables: The total of interchangeable bases in the surface soil showed the most significant variation (MD - mode deviation $-=0.82$ ), followed by the $\mathrm{pH}$ of the surface soil in a soil-water solution $(\mathrm{MD}=0.79)$ and base saturation in the surface soil $(\mathrm{MD}=0.72)($ Table 4$)$.

Table 4. Ecogeographic variability with qualitative characteristics in the cassava collection from Ecuador.

\begin{tabular}{lcl}
\hline Variables & $\begin{array}{c}\text { Gradient/ } \\
\text { Soil type } \\
\text { deviation } \\
\text { index }\end{array}$ & Type \\
\hline Slope & 0.28 & Flat \\
Total interchangeable bases in the soil surface & 0.82 & High fertility \\
Organic carbon content in the soil surface & 0.49 & Low \\
Cation exchange capacity in the surface soil & 0.76 & Low \\
Cation exchange capacity of the clay in the surface & 0.59 & Very high \\
Reference of the apparent density of the soil surface soil & 0.48 & Volcanic soil horizons \\
Apparent density reference of the subsoil & 0.28 & Volcanic soil horizons \\
The pH of the surface soil in a water and soil solution & 0.79 & Slightly acidic \\
The pH of the subsoil in a water and soil solution & 0.68 & Slightly acidic \\
The saturation of the bases in the surface soil & 0.72 & A very acidic soil \\
\hline
\end{tabular}

\section{Multivariate analysis: Groups description}

Based on the multivariate grouping analysis with quantitative data, three different groups were obtained (Fig. 4). 


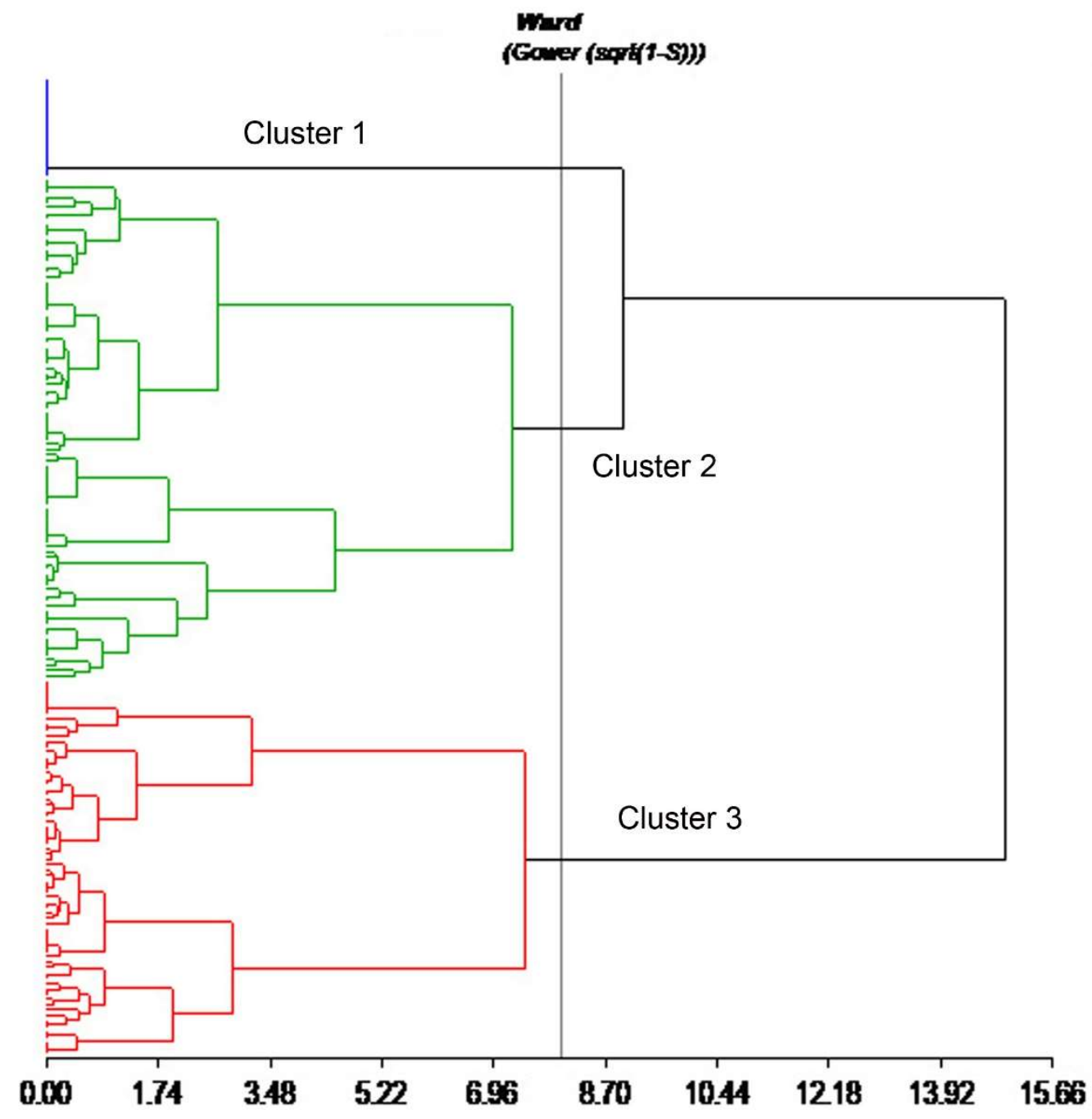

Figure 4. Dendrogram of the Ecuadorian cassava collection indicating 3 groups of accessions based on quantitative ecogeographic data using Ward's method and Gower's distance.

\section{Group 1.}

Regarding the qualitative characteristics (Appendix 5), group 1 accessions develop mainly on flat slopes, surface soil with low fertility for exchangeable bases, low carbon content on the surface, low cation exchange capacity on the soil surface, medium clay exchange capacity, volcanic soil horizons as a reference of apparent density in surface and subsoil soil, very acid pH in soil and subsoil and very acid soils for base saturation in surface soil. Group 1 presents 19 accessions (Appendix 1) collected in a single province of the Ecuadorian coast called Manabí and specifically in the Santa Ana canton. Cassava ecotypes develop in this agro-ecological zone with an altitude of $347 \mathrm{~m}$ a.s.1. The temperature in April, recorded as the hottest month, was $29.2^{\circ} \mathrm{C}$, while the temperature in August was $17.4^{\circ} \mathrm{C}$ recorded as the coldest month. They are characterized by developing with rainfall of $845 \mathrm{~mm}$, recorded in the hottest quarter. The sand content in the soil was $30 \%$, in the 
subsoil; it was $20 \%$, while the gravel content in the subsoil was $1 \%$ (Appendix 4). The quantitative ecogeographic variables do not show variation for this group since the accessions were collected under similar conditions (Appendix 5).

Regarding the qualitative ecogeographic characteristics, group 1 (Appendix 5) develops on i. flat slopes, surface soil; ii. high fertility soil for exchangeable bases; iii. medium carbon content on the surface; iv. medium cation exchange capacity on the soil surface; v. very high clay exchange capacity; vi. volcanic soil horizons as a reference of apparent density in surface and subsoil soil; vii. moderately acidic $\mathrm{pH}$ in soil, and viii. subsoil and medium base saturation in the soil.

\section{Group 2.}

Group 2 presents 95 accessions (Appendix 1) mainly from provinces of the Costa region: Esmeraldas, Manabí, Santo Domingo, Los Ríos, Guayas, Cañar, and Azuay to more than seven accessions from the Amazon province of Fco. De Orellana. Once again, the provinces of Cañar and Chimborazo are known as Sierra region (highlands). However, the collection sites are from lowland areas (La Troncal) or foothills of the western mountain range (Cumandá), respectively.

The quantitative ecogeographic variables with the most significant variation for this group were i. average rainfall for October (183.2\%), for August (170.1\%) and for May (87.68\%); ii. gravel content in subsoil (121.4\%), and iii. altitude (65.67\%). The accessions of this group correspond to a very hot environment $\left(23.5^{\circ} \mathrm{C}\right.$ to $\left.26^{\circ} \mathrm{C}\right)$; however, it is noteworthy that higher temperatures $\left(28.5^{\circ} \mathrm{C}\right.$ to $\left.31.2^{\circ} \mathrm{C}\right)$ were recorded in February, $\left(28.8^{\circ} \mathrm{C}\right.$ to $31.5^{\circ}$ $\mathrm{C})$ in March, and $\left(29.1^{\circ} \mathrm{C}\right.$ at $\left.31.9^{\circ} \mathrm{C}\right)$ in April as the highest temperature registered. In the same way, these accessions bear minimum temperatures recorded in August $\left(17.9^{\circ} \mathrm{C}\right.$ to $\left.22.1^{\circ} \mathrm{C}\right)$, similar to the minimum temperature of September $\left(10^{\circ} \mathrm{C}\right.$ to $\left.21.8^{\circ} \mathrm{C}\right)$ and the minimum temperature recorded in October $\left(18.3^{\circ} \mathrm{C}\right.$ to $\left.22^{\circ} \mathrm{C}\right)$. Concerning precipitation, the average for May was $9 \mathrm{~mm}$ to $329 \mathrm{~mm}$. It was from $2 \mathrm{~mm}$ to $208 \mathrm{~mm}$ for August, while in October, it was registered $3 \mathrm{~mm}$ to $310 \mathrm{~mm}$. In relation to soil, this group of accessions develop in soil with a sand content of 18 at $70 \%$, while the sand content in the subsoil was from 18 to $70 \%$ (Appendix 4).

Regarding the qualitative ecogeographic characteristics, group 2 (Appendix 5) develops i. mainly on flat slopes; ii. surface soil with low fertility for exchangeable bases; iii. low carbon content on the surface; iv. medium cation exchange capacity on the soil surface; v. very high clay exchange capacity; vi. volcanic soil horizons as a reference of apparent density in surface and subsoil soil; vii. slightly acidic $\mathrm{pH}$ in soil and subsoil; and, vii. soil saturated in bases.

\section{Group 3.}

The third group comprises 81 accessions (Appendix 1) mainly from the Ecuadorian Amazon region, from the provinces of Sucumbíos, Napo and Fco. De Orellana Pastaza, Morona Santiago Zamora Chinchipe and Tungurahua. The latter province is known as the Andean province; however, "Baños", located in the foothills of the Andes, is known as the door of the Ecuadorian Amazon towards the province of Pastaza.

The quantitative ecogeographic variables with the greatest variation for this group were i. gravel content in the subsoil (CV 146.4\%); ii. sand content in the subsoil (CV 48.87\%); iii. sand content in the soil (CV 48, 66\%); iv. altitude (CV 48.43\%); v. mean rainfall for August (CV 22.94\%); vi. minimum temperature for June (CV 21.38\%) and vii. mean 
rainfall for May (CV $21.25 \%$ ). The accessions of this group present a wide range of adaptation between $255 \mathrm{~m}$ a.s.1. and $1566 \mathrm{~m}$ a.s.1., support minimum temperatures between $12.9^{\circ} \mathrm{C}$ to $19.5^{\circ} \mathrm{C}$, the same that occurred in August. The precipitation recorded during the hottest quarter, i.e. three hottest months, was $420 \mathrm{~mm}$ to $1074 \mathrm{~mm}$. In addition, the average rainfall for May is between $183 \mathrm{~mm}$ to $470 \mathrm{~mm}$, average rainfall for August between 118 $\mathrm{mm}$ to $349 \mathrm{~mm}$, average rainfall for October between $149 \mathrm{~mm}$ and $367 \mathrm{~mm}$. The sand content in the soil is between $11 \%$ and $58 \%$, the sand content in the subsoil between $13 \%$ and $64 \%$ and gravel content in the subsoil between $0 \%$ and 49\% (Appendix 4).

Regarding the qualitative characteristics, group 3 accessions develop mainly on i. flat slopes; ii. surface soil with low fertility for exchangeable bases; iii. low carbon content on the surface; iv. low cation exchange capacity on the soil surface; v. very high capacity for clay exchange; vi. volcanic soils as a reference of apparent density in surface and subsoil soil, vii. slightly acidic pH for soil, subsoil, and viii. soil saturated in bases (Appendix 5).

\section{DISCUSSION}

\section{MORPHOLOGY}

\section{Descriptors of the aerial part}

The shape descriptor of the central lobe of the leaf was elliptical-lanceolate and lanceolate with $50.0 \%$ and $40.0 \%$ respectively of the total accessions. In this study, the lanceolate leaf form occurs in almost all the accessions studied, in agreement with [37,21] but differs from the results of Meneses et al. [23] who, when characterizing 40 accessions, did not show variation in this characteristic. Similarly, [38] report that when characterizing 19 cassava clones, they found that $13.3 \%$ of the total presented the oval-lanceolate lobe shape.

The accessions presented three shades of apical leaf colour in the following order: light green, dark green and purple-green. In this regard, [39] mention that the light green colour is an easily observable and highly heritable attribute, and it is also expressed in the same way in any environment, which contributes to better discrimination of phenotypes $([40,41]$. The results obtained agree with Meneses et al. [23], who indicate that most of the 40 accessions presented a light green colour in the apical bud, followed by dark green. Also, [42] indicate that the apical leaf colour: dark purple and light green. It is important to note that the colour of the apical shoot developed purple-green and purple colouration. Ceballos and de la Cruz [40] mention that it is common to observe purple shoots, but as the leaves grow and develop, they change to a greenish colouration.

Of the total accessions, $52 \%$ did not present apical leaf pubescence and $48 \%$ presented pubescence. These results differ as indicated by Meneses et al. [23], who determined that, of 40 accessions, $87.5 \%$ had the presence of apical bud pubescence, and $12.5 \%$ did not present this characteristic. Similarly, Torres [41] reported a $78.0 \%$ presence of pubescence and an absence of $22.0 \%$, while [21] observed a presence in $100 \%$ of the accessions evaluated.

About the colour of the epidermis of the stem, $57 \%$ were observed with dark green colour and $26 \%$ with light green colour. These results do not agree with those obtained by Meneses et al. [23], who indicated that $90 \%$ of the accessions evaluated. They presented a light brown colour followed by a cream colour. Koefender et al. [21] observed that the light brown colour appeared $51.06 \%$ in the evaluated accessions. This descriptor, according to 
Ramos [42], is a characteristic that may differ between genotypes and in the different stages of plant growth; for example, in the juvenile phase, different shades may appear from light red, brown and green. In addition, it is essential to take into account that edapho-climatic factors and cultivation practices can infer in this descriptor due to the availability of nutrients in the soil and their assimilation by plants [21]. On the other hand, the colour of the terminal branch of the adult plant developed in the collection was dark green (49\%) and light green (31\%). Results different from those found by Torres [40], who found that of 37 accessions, 32 were green, four were green, and one was purple; and Meneses et al. [23] who indicate a purplish-green $(57.5 \%)$ and green $(42.5 \%)$ colour.

The inflorescence was present in 144 accessions (74.0\%), and there was no flowering in 51 accessions (26.0\%). This observation coincides with findings by [43], who found that $96.45 \%$ of the accessions under study flowered and 3.5\% did not flower. Koefender et al. [21] observed flowering and the presence of fruits in all the evaluated plants. According to Marín et al. [38], flowering is essential for plant breeding since it allows making crosses between selected clones and thus obtaining new genetically superior individuals; the most common form of propagation and / or multiplication is vegetative reproduction by cuttings.

\section{Root descriptors}

In cassava, the economically most important characteristic is the pulp. White pulp is one of the colour preferred in producing flours, and selling as fresh products in local markets $[40,44]$. Of the 195 accessions of the cassava collection, $83.0 \%$ of the accessions presented a white pulp colour and only $13.0 \%$ a cream colour; in addition, $5.0 \%$ was yellow. Meneses et al. [23] indicate opposite results to the white and cream colour, but agrees with the low percentage of yellow pulp. $57.5 \%$ of the accessions developed a cream pulp colour while $37.5 \%$ white pulp; However, two accessions with yellow pulp were found $(5.0 \%)$, while Koefender et al. [21] indicate contrary data, the highest frequency was presented in the cream colour (47\%), followed by the white colour (35\%) and the yellow (18\%).

Another characteristic of the fresh market is the ease of peeling [44]. Of the total accessions studied, $88.0 \%$ presented ease of peeling, and only $12.0 \%$ presented difficulty. These results coincide with those reported by Meneses et al. [23], who indicate that only $12.0 \%$ of the accessions presented peeling difficulty of the 40 accessions. Again, this characteristic is related to texture since it was mainly found that difficult-to-peel accessions have a rough and intermediate texture $(94.0 \%)$, and those easy to peel have a soft texture $(6.0 \%)$.

\section{Discriminant morphological characters}

The qualitative descriptors that allowed better discrimination between the groups obtained in the statistical analysis were petiole colour, the shape of the central lobe, the colour of the epidermis of the stem, and the colour of the adult plant's terminal branches. It can be observed that there are descriptive characters for both the leaf and the stem of the plant. Furthermore, according to what is stated by Ramos [42] and Lowe et al. [45], they correspond to descriptors of vegetative and reproductive organs that are easily quantifiable and highly heritable, which are not significantly influenced by the environment. In the study carried out by Demey et al. [46], as in this research, the colour of the terminal branches of the adult plant is pointed out as the most significant characteristic in separating the groups. This finding means that the descriptors i. the form of the central lobe, ii. the 
colour of the petiole and iii. the colour of the terminal branches of the adult plant could be recommended to characterize cassava accessions. Additionally, some qualitative descriptors presented more significant variability in this study coincided with those indicated by Lobo [17].

Of the nine quantitative characters, four were the most discriminating between groups; two are related to the root: root length and mean root weight per plant; and the others: height at the first branch and plant height. The descriptors mean weight of the root per plant and height of the first branch presented the highest variation, possibly due to the influence of the environment. In contrast, four of the nine descriptors evaluated, such as the number of lobes, lobe length, lobe width, and length between nodes, presented a low coefficient of variation, indicating homogeneity in the results and, therefore, the existence of good handling of the experiment. The root length descriptor, in this study, is also considered discriminant in the research conducted by Acosta et al. [39], so it can be recommended for future characterizations of cassava.

In the groupings, 27 quantitative and qualitative descriptors were used to distinguish the 195 cassava accessions in four different groups, which coincides with Dominguez [47], who mention that cassava shows a wide variability and presents a high degree of intraspecific hybridization. The results of this study are similar to other studies $[48,49]$ that used descriptors such as tuber length, epidermis colour, external skin of the tuber colour, the texture of the tuber surface and the colour of the pulp to make a difference between groups. The quantitative descriptors that presented more variability are the total fresh weight of the storage roots per plant and height at the first branch. These morphological descriptors are influenced by the cultivar and environment interaction [50,51].

Morphological traits (qualitative and quantitative) are quite variable but helpful for preliminary evaluation (pre-breeding) and have been used by local farmers empirically to identify and in the primary selection of plant material. The phenotypic identification of plants has been used in genotypic classification and taxonomic studies [52,53].

\section{Environmental adaptation characteristics of the cassava collection}

Ecuador is located in the tropical belt, just above the equinoctial line, making it very diverse in terms of climatic and edaphic conditions, in addition also presents rich ethnic and cultural diversity. In this study, it has been determined that cassava develops in seven life zones with wide ranges of altitude, soil and climatic conditions, which shows its wide adaptability [54]. This observation agrees with Sharkawy and Cadavid [55], who mentions that cassava cultivation worldwide grows in a wide range of conditions from the humid and warm lowland tropics, through the mid-altitude tropics, to the subtropics with cold winters and summer rains; conditions that make it suitable for combating climate change [56,57].

The materials that make up the Ecuadorian collection were collected at altitudes between 5 and $1566 \mathrm{~m}$ a.s.l., which coincides with El-Sharkawy [58], who mention that cassava is sown from sea level to altitudes of 2,000 $\mathrm{m}$ a.s.l. in tropical countries located in the equatorial range between $30^{\circ}$ north and $30^{\circ}$ south. The same author [58] mentions the development of cassava cultivation with annual rainfall between 500 and more than 2,000 $\mathrm{mm}$. Our study identified that the rainfall in the cultivation sites, during the hottest quarter 
was a minimum of $193 \mathrm{~mm}$ and a maximum of $1615 \mathrm{~mm}$, which would imply that there are materials resistant to drought. Drought is one of the most important adaptation characteristics of the crop [59,60], and it can be evaluated [61]. On the other hand, the annual mean temperature range of the collection ranges from $18.4^{\circ} \mathrm{C}$ to $26^{\circ} \mathrm{C}$, which also indicates an important range of adaptation. In short, adaptation characteristics to changes in temperature and precipitation of cassava are highly desirable for a crop that can feed the world population in times of climate change by expanding production areas worldwide $[56,57,62]$.

Cassava is a crop that adapts to marginal, acidic soils and enables it to grow almost without the application of pesticides, allowing it to adapt even to marginal areas of Africa $[59,63,64]$. The data indicate that in Ecuador, most of the accessions, especially in the Amazon region (Group 1, Appendix 1), grow in soils with low nutrient content and acidic $\mathrm{pH}$. However, on the coast of Ecuador, the soils dedicated to cassava planting have high fertility, so cassava is one of the transitory crops with the highest production in the region [65]. In the Costal region, the crop can be grown in monoculture or mixed with maize to be commercialized [66]. In contrast, in the Ecuadorian Amazon, cassava production is more dedicated to subsistence consumption, where several traditional cassava cultivars coexist in the chagra (plot) of individual farmers; as, for example, in the Kiwicha communities of Napo, where cassava is known by the generic name 'Lumu' [67]. Furthermore, cassava in the Ecuadorian and Colombian Amazon region has high cultural importance [68]. This type of management is similar to Africa's traditional agroecosystems, where farmers tend to cultivate a great diversity of varieties per crop species that can reduce the risk of crop failure due to climate impacts, diseases, pests and soil limitations $[69,70]$.

Finally, we can indicate that the applications of ecogeography and geographic information systems $[25,71]$ have proven essential to characterize the conditions in which cassava cultivation develops in Ecuador and identify accessions that can adapt to conditions, e.g. extreme drought and poor soils, which could be used for improvement of this important crop.

\section{REFERENCES}

1. Organización de las Naciones Unidas para la Agricultura y la Alimentación (FAO) y Fondo Internacional de Desarrollo Agrícola (FIDA). La economía mundial de la yuca: hechos, tendencias y perspectiva. Roma, Italia. 2000.

2. Aristizábal, J.; Sánchez, T. Guía técnica para producción y análisis de almidón de yuca. Boletín de servicios agrícolas de la FAO, 2007, 163.

3. Organización de las Naciones Unidas para la Agricultura y la Alimentación (FAO). Ahorrar para crecer: La yuca. Guía a la intensificación sostenible de su producción. Roma, Italia. 2013, 24 p. Available online: http://www.fao.org/3/i2929s/i2929s.pdf (accessed on 14 September 2020).

4. Ademiluyi, F.T.; Mepba, H.D. Yield and properties of ethanol biofuel produced from different whole cassava flours. Int. Sch. Res. Notices, 2013. ID 916481, doi: $\underline{10.5402 / 2013 / 916481}$ 
5. Awoyale, W.; Sanni, L.O.; Shittu, T.A.; Adegunwa, M.O. Effect of storage on the chemical composition, microbiological load, and sensory properties of cassava starchbased custard powder. Food Sci. Nutr. 2015, 3(5), 425-433, doi:10.1002/fsn3.235

6. Hinostroza, F.; Mendoza, M.; Navarrete, M.; Muñoz, X. Cultivo de yuca en el Ecuador. Estación Experimental Portoviejo de INIAP. Boletín Divulgativo 2014, 436, 28p. Available online: https://repositorio.iniap.gob.ec/bitstream/41000/5214/1/ INIAPEEPbd436.pdf (accessed on 15 December 2020).

7. Pérez, H.; Rodríguez, I. Cultivos Tropicales de Importancia Económica en Ecuador (Arroz, Yuca, Caña de Azúcar y Maíz). Machala-Ecuador, UTMACH. 2017.

8. Organización de las Naciones Unidas para la Agricultura y la Alimentación (FAO). Datos sobre alimentación y agricultura. Roma, Italia. 2020. Available online: http://www.fao.org/faostat/es/\#search/yucca (accessed on 25 October 2020).

9. Muñoz, X.; Hinostroza, F.; Mendoza, M. La yuca en Ecuador: su origen y diversidad genética / Cassava in Ecuador: its origin and genetic diversity. El Misionero del Agro. 2017, 16,4, 2-18. Available online: http://181.198.35.101/web/revistas_cientificas/ revista_cientifica_16.pdf (accessed on 25 January 2021).

10. Ministerio de Cultura y Patrimonio. Patrimonio Alimentario, Yuca Amazónica. Quito, Ecuador. 2016. Available online: https://patrimonioalimentario.culturaypatrimonio. gob.ec/wiki/ index.php/Yuca_Amazon\%C3\%ADa (accessed on 4 February 2021).

11. Barrera, V.; Cruz, E.; Cárdenas, F.; Cobeña, G.; Zambrano, H. Estrategias de vida de las comunidades de pequeños/as productores/as de yuca (Manihot esculenta Crantz) en Manabí-Ecuador. INIAP-SENACYT. Quito-Ecuador. 2010. 79 pp.

12. Dominguez, C.E. Morphology of the cassava plant: Study guide. CIAT (Centro International de Agricultural Tropical), Cali Colombia. 1984, Serie 04EC-02.03, 44 p. Available online: http://ciat-library.ciat.cgiar.org/articulos_ciat/books/Morphology of the casava plant.pdf (accessed on 25 January 2021).

13. Van Hintum, T.J.L. Hierarchical approaches to the analysis of genetic diversity in crop plants. In Core Collection of Plant Genetic Resources. Hodgkin, T., Brown, A.H.D., van Hintum, T.J.L., Morales, E.A.V. Eds.; A Wiley-Sayce Publication, Chichester, UK 1995, pp. 23-34

14. Abadie, T.; Ceretta, S. Exploring crop adaptation through the study of multi environment trials (METs). In $3^{\text {rd }}$ South American Oats Congress. La Estanzuela, Colonia, Uruguay, Montevideo Rebuffo, M., Abadie, T. Eds.; Instituto Interamericano de Cooperación para la Agricultura (INIA) \& The Quaker Oats Company. 1997, pp. 35-40.

15. Furman, B.; Qualset, C.; Skovmand, B.; Heaton, J.; Wesenberg, D. Characterization and analysis of North America Triticale genetic resources. Crop Sci. 1997. 37(6), 1951-1959, doi:10.2135/cropsci1997.0011183X003700060046x

16. Abadie, T.; Berreta, A. Caracterización y evaluación de recursos fitogenéticos. In Estrategia en recursos fitogenéticos para los países del Cono Sur. Berretta, A, Rivas, M. Eds.; Procisur. Documentos. Montevideo, Uruguay, 2001, pp. 91-99. Available online: http://www. procisur.org.uy/adjuntos/plataforma-regional/21.pdf (accessed on 13 July 2020). 
17. Lobo, R. Descriptores para la caracterización de yuca (Manihot esculenta Crantz). In Conservación in situ de cultivos nativos y parientes silvestres. Estrada, R., Medina, T., Roldán, A. Eds., Lima, Perú: Instituto Nacional e Investigación y Extensión Agraria. 2006, pp. 136-169. Available online: http://www.iiap.org.pe/upload/publicacion/ publ459.pdf (accessed on 4 February 2021).

18. Fukuda, W.M.G.; Guevara, C.L. Descritores morfológicos y agronómicos para a caracterizaçión de yuca (Manihot esculenta Crantz). Cruz das Almas: Empresa Brasileira de Pesquisa Agropecuária (EMBRAPA-CNPMF), Documentos, 78, Bahia, Brazil, 1998, 38 p.

19. Mejía, J.; Elias-Da Silva, R.; Mejía, K.; García-Dávila, C. Caracterización Morfológica y Genética de Etnovariedades de la Yuca Manihot esculenta Cranz, en 6 localidades de la Cuenca baja del río Ucayali-Perú. Folia Amazón. 2015, 24(1), 71-82.

20. Agre, A.P.; Dansi, A.; Rabbi, I.Y.; Bhattacharjee, R.; Dansi, M.; Melaku, G.; Augusto, B.; Sanni, A.; Akouegnon, A.; Akpagana, K. Agromorphological Characterization of Elite Cassava (Manihot esculenta Crantsz) Cultivars Collected in Benin. Int. J. Curr. Res. Biosci. Plant Biol. 2015, 2(2), 1-14. Available online: http://www.ijcrbp.com/vol2-2/A.P.\%20Agre, \%20et\%20al.pdf (accessed on 25 October 2020).

21. Koefender, J.; Golle, D.P.; Manfio, C.E.; Horn, R.C.; Schoffel, A.; De Oliveira, J.A.R.; Camera, J.N. Caracterización Morfológica y Agronómica de Accesos en yuca en la region nordeste del Río Grande do Sul, Brasil. HOLOS, 2018, 34,6, 2-15. doi:10.15628/holos.2018.7747

22. N'Zué, B.; Pamelas, O.M.; Michel, K.A.; Brice, D.K.E.; Pierre, Z.G.; Sidoine, E.B.; Alexandre, D.A. Morphological characterization of cassava (Manihot esculenta Crantz) accessions collected in the centre-west, south-west and west of Côte d'Ivoire Greener J. Agric. Sci. 2014, 4,6, 220-231, doi:10.15580/GJAS.2014.6.050614224

23. Meneses, I.; Núñes, R.; Andrés, P.; Aguilar, N.; Del Rosario, J.L.; Becerra, E.N.; Leyva, O.R.; Rosas, X.; Galindo, M.E., Cebada, M. Caracterización Morfológica de Accesiones de Yuca Manihot esculenta Crantz Recolectadas en el Estado de Chiapas, México. In Seguridad Alimentaria: Aportaciones Cientificas y Agrotecnológicas Martínez, Ramírez y Cámara-Córdova Eds.; 2017, pp. 419-423. ISBN:978-607-606425-2. Available online: http://www.archivos.ujat.mx/2017/div daca/publicaciones/ Seguridad\%20 Alimentaria\%20aportaciones\%20cientificas\%20y\%2 0agrotecnologicas.pdf (accessed on 2 September 2020).

24. Parra-Quijano, M.; Draper, D.; Torres, E.; Iriondo, J.M. Ecogeographical representativeness in crop wild relative ex situ collections. In Crop wild relative conservation and use. Maxted, N., Ford-Lloyd, B.V., Kell, S.P., Iriondo, J.M., Dulloo, M.E., Turok, J. Eds.; Cab International, Wallingford, UK. 2008. 249-273.

25. Parra-Quijano, M.; Iriondo, J.M.; Torres, E. Review. Applications of ecogeography and geographic information systems in conservation and utilization of plant genetic resources. Span. J. Agric. Res. 2012, 10(2), 419-429, doi:10.5424/sjar/2011102-303-11

26. Mezghani, N.; Khoury, C.K.; Carver, D.; Achicanoy, H.A.; Simon, P.; Flores, F.M.; Spooner, D. Distributions and Conservation Status of Carrot Wild Relatives in Tunisia: 
A Case Study in the Western Mediterranean Basin. Crop Sci. 2019, 59,6,_2317-2328. doi/10.2135/cropsci2019.05.0333

27. Sánchez González, J. de J.; Ruiz Corral, J.A.; García, G.M.; Ramírez Ojeda, G.; De la Cruz Larios, L.; Holland, J.B.; Miranda Medrano, R.; García Romero, G.E. Ecogeography of teosinte. Plos ONE 2018, 13(2), e0192676. doi:10.1371/ journal.pone.0192676

28. Parra-Quijano, M.; Torres Lamas, E.; Iriondo Alegría, J.M.; López, F. Herramientas CAPFITOGEN para la conservación y utilización de los recursos fitogenéticos para la alimentación y la agricultura. Versión 2. Organización de las Naciones Unidas para la Alimentación y la Agricultura. $1^{\text {st }}$ Ed. Madrid. 2015. Available online: http://www.fao. org/3/i3700s/ i3700s.pdf (accessed on 15 April 2021).

29. Tapia, C.; Torres, E.; Parra-Quijano, M. Searching for adaptation to abiotic stress: Ecogeographical analysis of highland Ecuadorian maize. Crop Sci. 2015, 55,1, 262274. doi:10.2135/cropsci2013.12.0813

30. Borja Borja, E.J. Caracterización eco-geográfica de Prunus serotina Ehrh subsp. capuli (Cav.) McVaugh (capulí), en la región andina de Ecuador (MSc thesis). Universidad de Valencia. España. 2017. 61 p.

31. Naranjo, E.; Tapia, C.; Velázquez, R.; Cruz, Y.; Delgado, A.; Borja, E.; Paredes, N. Caracterización Eco-geográfica de melloco (Ullucus tuberosus C.) En la Región Alto Andina del Ecuador. La Técnica, 2018. 19, 31-46. ISSN 1390-6895, ISSN-e 24778982 ,

32. Monteros-Altamirano, Á.; Tacán, M.; Peña, G.; Tapia, C.; Paredes, N.; Lima, L. Guía para el manejo de los recursos fitogenéticos en Ecuador. Protocolos. INIAP, Estación Experimental Santa Catalina. Departamento Nacional de Recursos Fitogenéticos, Mejía, Ecuador. Publicación miscelánea, 2018, 432, 1-104. Available online: https://repositorio.iniap. gob.ec/handle/41000/4889 (accessed on 11 June 2021).

33. Portilla Farfán, F. Agroclimatología del Ecuador. Universidad Salesiana. Abya Yala. $1^{\text {st }}$ Ed. Cuenca, Ecuador, 2018. 647 p. ISBN-UPS 978-9978-10-310-4. Available online: file:///C:/Users/ zdt536/AppData/Local/Temp/Agroclimatologia\%20del\%20 Ecuador.pdf (accessed on 25 February 2021).

34. MAG, (Ministerio de Agricultura y Ganadería). Memoria Explicativa del Mapa de Órdenes de Suelos del Ecuador, 2003, 15 p. Available online: http://metadatos. sigtierras.gob.ec/pdf/MEMORIA_MAPA_DE_ORDENES_DE_SUELOS_MAG_SIG TIERRAS.pdf (accessed on 16 February 2021)

35. Di Rienzo, J.; Casanoves, F.; Balzarini, M.; Gonzalez, L.; Tablada, M.; Robledo, C. InfoStat. Grupo InfoStat, FCA, Universidad Nacional de Córdoba, Argentina. 2018. URL Available online: http://www.infostat.com.ar (accessed on 25 February 2021).

36. Wilcox (1973) Indices of cualitative variation and political measurement the westem Political Quarterly 26:325-343.

37. Brito, C.L.L.; Viana, A.E.S.; Barbosa, G.M.; Lopes, S.C.; Santos, V.S.; Silva, V.A. Caracterização de clones de madioca (Manihot esculenta Crantz) por meio de descritores morfológicos em Cândido Sales-Bahia. Congreso Brasileiro de Mandioca, 15. Salvador, Brazil, 2013. Available online: https://ainfo.cnptia.embrapa.br/digital/ 
bitstream/item/95814/1/CARACTERIZA;CAO-DE-CLONES-152-pratica-21468VANDERLEI.pdf (accessed on 12 November 2020).

38. Marín, A.; Perdomo, D.; Albarrán, J.G.; Fuenmayor, F.; Zambrano, C. Evaluación agronómica, morfológica y bioquímica de clones élites de yuca a partir de vitroplantas. Interciencia, 2008. 33,5, 365-371. Available online: http://www.redalyc.org/articulo. oa?id=3393350 (accessed on 15 December 2020).

39. Acosta, R.; Tamayo, A.; Palacios, R. Caracterización morfológica y extracción de ADN de 11 clones de yuca (Manihot esculenta Crantz) en la Universidad de EARTH, Costa Rica. Tierra Tropical, 2006, 2,1, 67-75. Available online: http://usi.earth.ac.cr/ glas/sp/PGs2003-2007.pdf (accessed on 25 October 2020).

40. Ceballos, H.; de la Cruz, G.A. Taxonomía y morfología de la yuca. In La yuca en el tercer milenio. Ospina, B., Ceballos, H. Eds.; Centro Internacional de Agricultura Tropical, Cali, Colombia, 2002; pp. 15-32. Available online: http://passthrough.fwnotify.net/download/496110/http://www.clayuca.org/sitio/images/publicaciones/yuca t ercer_milenio.pdf (accessed on 12 November 2020).

41. Torres, L. Caracterización morfológica de 37 accesiones de yuca (Manihot esculenta Crantz) del banco de germoplasma del Centro Agronómico Tropical de Investigación y Enseñanza (CATIE). (Tesis de Magister Scientiae), Centro Agronómico Tropical de Investigación y Enseñanza, Turrialba. Turrialba, Costa Rica. 2010, 88 p. Available online: http://passthrough.fw-notify.net/download/262766/http://www.sidalc.net/ repdoc/a5955e/a5955e.pdf (accessed on 15 August 2020).

42. Ramos, P.A.S. Caracterização Morfológica e Produtiva de nove variedades de mandioca cultivadas no Sudoeste de Bahia. Dissertação (MSc Phytotecnia). Universidade Federal de Viçosa, Viçosa, Brazil. 2007, 60 p. Available online: https://locus.ufv.br// handle/123456789/4647 (accessed on 25 October 2020).

43. Pincay Anchundia, L.M. Caracterización agronómica, morfológica y molecular del banco de germoplasma de yuca (Manihot esculenta Crantz) de la estación experimental Portoviejo del INIAP. Tesis profesional. Universidad Técnica de Manabí, Facultad de Agronomía, Manabí, Ecuador. 2010, 61 p. Available online: http://repositorio.iniap. gob.ec/handle/41000/4111 (accessed on 15 August 2020).

44. Polanco, D. Caracterización morfológica, isoenzimática, contenido de cianuro y almidón en el banco de germoplasma in vivo de yuca (Manihot esculenta Crantz) de la Facultad de Agronomía dela Universidad Central de Venezuela. Tesis profesional. Universidad Central de Venezuela. Maracay, Venezuela. 1998, 99 p. Available online: http://ve.scielo.org/scielo.php?script=sci_nlinks\&

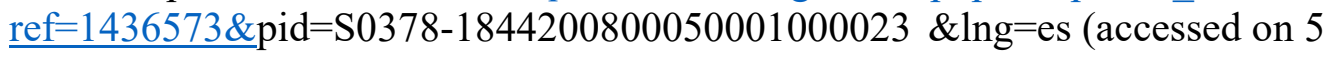
July 2020).

45. Lowe, A.; Hanotte, O.; Garino, L. Standardization of molecular genetic techniques for the characterization of germplasm collection: the case of random amplified polymorphic DNA (RAPD). Plant Genet. Resour. Newslett. 1996, 107, 50-54. Available online: https:// cgspace.cgiar.org/handle/10568/29494 (accessed on 13 April 2021). 
46. Demey, J.; Zambrano, A.; Fuenmayor, F.; Segovia, V. Relación entre caracterizaciones molecular y morfológica en una colección de yuca. Interciencia, 2003, 28(12), 684689. Available online: www.interciencia.org (accessed on 5 July 2020).

47. Domínguez, C. Yuca: investigación, producción y utilización. Programa de Yuca. CIAT. Cali, Colombia. 1983. 656 p. Available online: http://ciat-library.ciat.cgiar.org/ Articulos_Ciat/Digital/SB211.C4_Y85_Yuca_Investigaci\%C3\%B3n,producci\%C3\%B 3n_y_utilizaci\%C3\%B3n.pdf (accessed on 25 October 2020).

48. Raghu, D.; Senthil, N.; Saraswathi, T.; Raveendran, M.; Gnanam, R.; Venkatachalam, R.; Shanmugasundaram, P.; Mohan, C. Morphological and simple sequence repeats (SSR) based finger printing of south Indian cassava germplasm. Int. J. Intergrat. Biol. 2007, 1, 141-149. Available online: http://www.classicrus.com/IJIB/Arch/2007/ 1020.pdf (accessed on 4 February 2021).

49. Ampong-Mensah, G. Preliminary Characterization of cassava Germplasm from SouthWestern Ecozone (Central and Western Region) of Ghana (Unpublished MPhill Thesis) Dept. Crop Sci. Univ. Cape Coast, Ghana. 2000, pp. 269-390.

50. Kaemmer, D.; Afza, R.; Weising, K.; Kahl, G.; Novak, F.J. Oligonucleotide and amplification fingerprinting of wild species and cultivars of banana (Musa spp). Biol. Technol. 1992, 10, 1030-1035. doi:10.1038/nbt0992-1030

51. Gepts, P. The use of molecular and biochemical markers in crop evolution studies. Evol. Biol. 1993, 27, 15-94. doi:10.1007/978-1-4615-4235-3 13

52. Bonierbale, M.; Guevara, C.; Dixon, A.G.O.; Ng, N.Q.; Asiedu, R.; Ng, S.Y.C. Cassava. In Biodiversity in Trust. Fuccilo, D., Sears, L., Stapleton, P. Eds.; Cambridge: Cambridge Univ. Press. 1997. pp. 1-20. Available online: https://books.google. com.co/books?id=jLOiSPWy518C\&lpg=PP1\&hl=es\&pg=PA1\#v=onepage\&q\& $\mathrm{f}=$ false (accessed on 25 October 2020).

53. Nassar, N.M.A. Cassava: Some ecological and physiological aspects related to plant breeding. An article published online with Gene Conserve. 2005; Available online: http:/www.geneconserve.pro.br/ (accessed on 1 February 2021).

54. Ecuador País de las Orquídeas. ¿Por qué Ecuador es un país megadiverso? 2013. Available online: http://visit.ecuador.travel/orquideas/index.php?option $=\mathrm{com}$ tz portfolio\&view=article\&id=66\%3 Por-que-ecuador-es-un-pais-megadiverso\&catid $=16 \&$ Itemid $=110$ (accessed on 01 February 2021)

55. Sharkawy, M.A.; Cadavid, L. Genetic variation within cassava germplasm in response to potassium. Exper. Agric. 2000, 36(3), 323-334. doi:10.1017/S0014479700003045

56. Jarvis, A.; Ramirez-Villegas, J.; Herrera Campo, B.V.; Navarro-Racines, C. Is Cassava the Answer to African Climate Change Adaptation? Tropical Plant Biol. 2012, 5, 9-29, doi:10.1007/s12042-012-9096-7

57. de Oliveira Aparecido, L.E.; da Silva Cabral deMoraes, J.R.; de Meneses, K.C.; Lorençone, P.A.; Lorençone, J.A.; de Olanda Souza, G.H.; Botega Torsoni, G. Agricultural zoning as tool for expansion of cassava in climate change scenarios. Theor. Appl. Climatol. 2020, 142, 1085-1095, doi:10.1007/s00704-020-03367-1 
58. El-Sharkawy, M.A. Stress-tolerant cassava: the role of integrative ecophysiologybreeding research in crop improvement. Open J. Soil Sci. 2012, 2(2), 162-186, doi: 10.4236/ojss.2012.22022.

59. Okogbenin, E.; Setter, T.; Ferguson, M.; Mutegi, R.; Ceballos, H.; Olasanmi, B.; Fregene, M. Phenotyping cassava for adaptation to drought: review. Front Physiol. 2013, 4, 93, doi:10.3389/fphys.2013.00093.

60. de Oliveira, E.J.; Aidar, S.T.; Morgante, C.V.; Rodrigues de Melo Chaves, A.; Lopez Cruz, J.; Coelho Filho, M.A. Genetic parameters for drought-tolerance in cassava. Pesq. Agropec. Bras., 2015, 50,3, 233-241, doi:10.1590/S0100-204X2015000300007

61. Nuwamanya, E.; Rubaihayo, P.R.; Mukasa, S.; Kyamanywa, M.; Hawumba, J.; Baguma, Y. Biochemical and secondary metabolites changes under moisture and temperature stress in cassava (Manihot esculenta Crantz). Afr. J. Biotechnol. 2014, 13, 31, 3173-3186, doi:10.5897/AJB2014.13663

62. Rivera-Hernández, B.; Aceves-Navarro, L.A.; Juárez-López, J.F.; Palma-López, D.J.; González-Mancillas, R.; González-Jiménez, V. Agroecological zoning and potential yield estimation of cassava (Manihot esculenta Crantz) in the state of Tabasco, México. Av. Investig. Agropecu. 2012, 16,1, 29-48. Available online: https://www. redalyc.org/articulo.oa?id=83723442003 (accessed on 15 April 2021).

63. Elias, M.; McKey, D.; Panaud, O.; Anstett, M.C.; Robert, T. Traditional management of cassava morphological and genetic diversity by the Makushi Amerindians (Guyana, South America): perspectives for on-farm conservation of crop genetic resources.

Euphytica 2001, 120, 143-157. Available online: https://www.academia.edu/ 14714146/Traditional_management_of_cassava_morphological_and_genetic_diversity _by_the_Makushi_Amerindians_Guyana_South_America_perspectives_for_on_ farm_conservation (accessed on 4 February 2021).

64. Burns, A.; Gleadow, R.; Cliff, J.; Zacarias, A.; Cavagnaro, T. Cassava: the drought, war and famine crop in a changing world. Sustainability 2010, 2,11, 3572-3607, doi: $10.3390 /$ su2 113572

65. INEC. Instituto Nacional de Estadística y Censos. 2011. Available online: www.ecuadorencifras.com: http://www.inec.gob.ec/espac_publicaciones/espac2011/espac.swf. (accessed: 11 February 2021).

66. Hinostroza-Garcia, F.; Cárdenas, F.M.; Álvarez, H.; Cobeña, G. INIAP Portoviejo 650. Una variedad de yuca para procesamiento. INIAP-SENESCYT. $3^{\text {rd }}$ ed. Tríptico. 2012, 2 p. https://repositorio.iniap.gob.ec/handle/41000/1115

67. Peñuela, M.; Schwarz, A.; Monteros-Altamirano, A.; Zurita-Benavides, M.; Cayapa, R.; Romero, N. Guía de la Agrobiodiversidad: Tres comunidades kichwa: Atacapi, Alto Tena y Pumayacu. Universidad Regional Amazónica IKIAM, Tena, Ecuador. 2016, 130 p. ISBN: 978-9942-8638-1-2. Available online: https://issuu.com/ 43347/docs/agrobiodiversidad_web_060217/3 (accessed on 25 October 2020).

68. Acosta Muñoz, L.E.; Zoria Java J. Ticuna traditional knowledge on chagra agriculture and innovative mechanisms for its protection. Instituto Amazónico de Investigaciones Científicas - Sinchi. Leticia, Colombia. Bol. Mus. Para. Emílio Goeldi. Cienc. Hum., Belém, 2012, 7,2, 417-433, doi:10.1590/S1981-81222012000200007 
69. Willemen, L.; Scheldeman, X.; Cabellos, V.S.; Salazar, S.R.; Guarino, L. Spatial patterns of diversity and genetic erosion of traditional cassava (Manihot esculenta Crantz) in the Peruvian Amazon: an evaluation of socio-economic and environmental indicators. Genet. Resour. Crop Evol. 2007, 154,7, 1599-1612, doi: 10.1007/s10722006-9172-7

70. Duputie,'A.; Massol, F.; David, P.; Haxaire, C.; McKey, D. Traditional Amerindian cultivators combine directionaland ideotypic selection for sustainable management ofcassava genetic diversity. J. Evol. Biol. 2009, 22,6, 1317-1325, doi:10.1111/j.14209101.2009.01749.x.

71. Parra-Quijano, M.; Iriondo, J.M.; Torres, E. Ecogeographical land characterization maps as a tool for assessing plant adaptation and their implications in agrobiodiversity studies. Genet. Resour. Crop Evol. 2012b, 59,2, 205-217, doi:10.1007/s10722-0119676-7. 
Appendix 1. Grouping by morphological and ecogeographical quantitative characters for the Ecuadorian collection of cassava.

\begin{tabular}{|c|c|c|c|}
\hline \multicolumn{4}{|c|}{ Grouping by morphological quantitative characters } \\
\hline Group 1 & Group 2 & Group 3 & Group 4 \\
\hline $\begin{array}{l}18414,18421,18429,18435, \\
18444,18453,18459,18461, \\
18470,18472,18487,18488, \\
18497,18540,18546,18564, \\
18566,18594,18597,18600, \\
18605,18616,19107,19136, \\
19149,19162\end{array}$ & $\begin{array}{l}17607,17615,17618,18407, \\
18415,18419,18423,18432, \\
18434,18440,18441,18448, \\
18451,18452,18455,18462, \\
18466,18468,18473,18476, \\
18479,18480,18483,18489, \\
18491,18495,18505,18506, \\
18510,18511,18513,18523, \\
18524,18536,18539,18541, \\
18542,18547,18559,18561, \\
18586,18587,18602,18607, \\
18610,18615,18620,18621, \\
19089,19113,19134,19141, \\
19150,19454\end{array}$ & 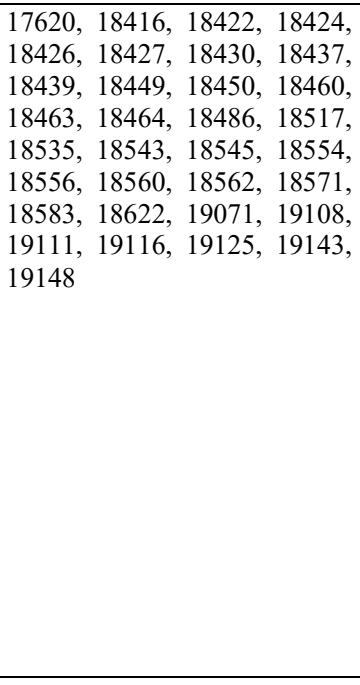 & $\begin{array}{l}17603,17604,17605,17608, \\
17611,17612,17614,17617, \\
17619,17621,17623,17624, \\
17625,17627,17628,17640, \\
18436,18456,18465,18477, \\
18485,18516,18522,18533, \\
18567,18599,18601,18608, \\
18618,19070,19091,19092, \\
19094,19095,19096,19097, \\
19098,19100,19101,19102, \\
19103,19104,19106,19109, \\
19110,19115,19117,19118, \\
19119,19120,19121,19122, \\
19123,19124,19126,19128, \\
19129,19130,19131,19132, \\
19133,19135,19137,19138, \\
19139,19140,19142,19144, \\
19145,19146,19147,19151, \\
19152,19153,19154,19155, \\
19156,19157,19158,19159, \\
19160,19161\end{array}$ \\
\hline \multicolumn{4}{|c|}{ Grouping by ecogegraphical quantitative variables } \\
\hline Group 1 & Group 2 & Group 3 & \\
\hline $\begin{array}{l}* 18583,18586,18587,18594, \\
18597,18599,18600,18601, \\
18602,18605,18607,18608, \\
18610,18615,18616,18618, \\
18620,18621,18622\end{array}$ & $\begin{array}{l}17640,18407,18414,18415, \\
18416,18419,18421,18422, \\
18423,18424,18426,18427, \\
18429,18430,18432,18434, \\
18435,18436,18437,18439, \\
18440,18441,18444,18448, \\
18449,18450,18451,18452, \\
18453,18454,18455,18456, \\
18459,18460,18461,18462, \\
18463,18464,18465,18466, \\
18468,18470,18472,18473, \\
18476,18477,18479,18480, \\
18483,18485,18486,18487, \\
18488,18489,18491,18495, \\
18497,18505,18506,18510, \\
18511,18513,18516,18517, \\
18522,18523,18524,18533, \\
18535,18536,18539,18540, \\
18541,18542,18543,18545, \\
18546,18547,18554,18556, \\
18559,18560,18561,18562, \\
18564,18566,18567,18571, \\
19152,19153,19154,19155, \\
19156,19157,19158\end{array}$ & $\begin{array}{l}17603,17604,17605,17607, \\
17608,17611,17612,17614, \\
17615,17617,17618,17619, \\
17620,17621,17623,17624, \\
17625,17627,17628,19070, \\
19071,19089,19091,19092, \\
19094,19095,19096,19097, \\
19098,19100,19101,19102, \\
19103,19104,19106,19107, \\
19108,19109,19110,19111, \\
19113,19115,19116,19117, \\
19118,19119,19120,19121, \\
19122,19123,19124,19125, \\
19126,19128,19129,19130, \\
19131,19132,19133,19134, \\
19135,19136,19137,19138, \\
19139,19140,19141,19142, \\
19143,19144,19145,19146, \\
19147,19148,19149,19150, \\
19151,19159,19160,19161, \\
19162\end{array}$ & \\
\hline
\end{tabular}

*(ECU) Gene bank codes at the National Institute for Agricultural Research (INIAP), Ecuador. 
Appendix 2. Morphological variability of quantitative characters based on the three groups obtained through multivariate analysis of the Ecuadorian cassava collection.

\begin{tabular}{|c|c|c|c|c|c|c|c|c|c|c|c|c|}
\hline \multirow{2}{*}{ Variables } & \multicolumn{6}{|c|}{ Group 1} & \multicolumn{6}{|c|}{ Group 2} \\
\hline & $\mathbf{n}$ & Mean & SD & $\mathrm{CV}$ & Mín & Max & $\mathbf{n}$ & Mean & SD & $\mathrm{CV}$ & Mín & Max \\
\hline $\begin{array}{l}\text { Total fresh weight of storage } \\
\text { roots per plant, } \mathrm{kg}\end{array}$ & 26 & 4.45 & 2.70 & 60.78 & 1.83 & 14.90 & 54 & 4.35 & 2.99 & 68.76 & 0.84 & 15.60 \\
\hline Height to first branching, $\mathrm{cm}$ & 25 & 11.83 & 47.90 & 42.84 & 10.00 & 210.00 & 52 & 103.28 & 38.13 & 36.92 & 30.00 & 200.00 \\
\hline Length of storage $r$ & 26 & 39.14 & 8.12 & 20.75 & 29.92 & 58.00 & 54 & 39.94 & 11.41 & 28.56 & 23.20 & 82.33 \\
\hline Plant height, $\mathrm{cm}$ & 25 & 231.24 & 71.70 & 31.01 & 98.00 & 350.00 & 52 & 237.90 & 58.74 & 24.59 & 127.00 & 330.00 \\
\hline Diameter of sto & 26 & 8.63 & 1.36 & 15.77 & 5.33 & 11.00 & 54 & 8.11 & 1.96 & 24.14 & 3.00 & 11.67 \\
\hline Distance b & 25 & 0.52 & 0.11 & 20.69 & 0.30 & 0.70 & 54 & 0.53 & 0.10 & 19.61 & 0.30 & 0.70 \\
\hline Width of le & 26 & 5.73 & 0.48 & 8.35 & 5.04 & 7.02 & 54 & 5.56 & 0.87 & 15.65 & 3.16 & 7.37 \\
\hline Number of leaf & 26 & 8.00 & 1.02 & 12.75 & 7.00 & 9.00 & 54 & 7.59 & 0.92 & 12.14 & 7.00 & 9.00 \\
\hline Length of leaf lobe, $\mathrm{cm}$ & 26 & 22.21 & 1.99 & 8.98 & 18.15 & 25.55 & 54 & 20.29 & 2.74 & 13.48 & 12.83 & 28.35 \\
\hline \multirow{2}{*}{ Variables } & \multicolumn{6}{|c|}{ Group 3} & \multicolumn{6}{|c|}{ Group 4} \\
\hline & n & Mean & SD & $\mathrm{CV}$ & Mín & Max & n & Mean & SD & $\mathrm{CV}$ & Iín & Max \\
\hline $\begin{array}{l}\text { Total fresh } \\
\text { roots per pla }\end{array}$ & 33 & 7.28 & 4 & 56.05 & 1.00 & 00 & 82 & 6.71 & 3.51 & 52.32 & 1.00 & 18.47 \\
\hline Height to firs & 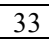 & .52 & 37.28 & 43.08 & 24.67 & 166.67 & 80 & 92.29 & 41.52 & 44.99 & 20.00 & 233.33 \\
\hline Lengt & 33 & .93 & 7.81 & 16.29 & 35.00 & 62.67 & 82 & 48.94 & 13.91 & 27.20 & 67 & 48.00 \\
\hline Plant height, $\mathrm{cm}$ & 33 & 261.15 & 59.91 & 22.94 & 83.00 & 350.00 & 80 & 261.59 & 59.20 & 22.63 & 90.00 & 393.00 \\
\hline Diameter of stora & 33 & 10.33 & 2.30 & 22.23 & 4.33 & 15.00 & 82 & 9.90 & 2.36 & 23.86 & 5.67 & 17.20 \\
\hline Distance between leaf scars, $c$ & 33 & 0.49 & 0.06 & 13.32 & 0.30 & 0.60 & 8 & 0.46 & 0.10 & 21.13 & .30 & 0.70 \\
\hline Width of leaf lobe, $\mathrm{cm}$ & 33 & 5.99 & 0.76 & 12.69 & 3.67 & 7.14 & & 5.45 & 1.05 & 19.17 & .48 & 8.57 \\
\hline Number of leaf lobes & 33 & 7.48 & 1.00 & 13.41 & 5.00 & 9.00 & 8 & 7.91 & 1.24 & 15.66 & 5.00 & 11.00 \\
\hline Length of leaf lobe, $\mathrm{cm}$ & 33 & 20.08 & 2.27 & 11.30 & 13.45 & 24.39 & 82 & 19.97 & 2.77 & 13.89 & 11.95 & 29.90 \\
\hline
\end{tabular}


Appendix 3. Morphological variability in qualitative characters based on the dendrogram groupings of the Ecuadorian cassava collection.

\begin{tabular}{|c|c|c|c|c|c|}
\hline State & Group 1 & Group 2 & Group 3 & Group 4 & Total \\
\hline \multicolumn{6}{|c|}{ Initial vigour of the plant } \\
\hline 1. Low & 0.19 & 0.46 & 0.48 & 0.46 & 0.43 \\
\hline 3. Intermediate & 0.81 & 0.50 & 0.52 & 0.46 & 0.53 \\
\hline 5. High & 0.00 & 0.04 & 0.00 & 0.07 & 0.04 \\
\hline Total & 1.00 & 1.00 & 1.00 & 1.00 & 1.00 \\
\hline \multicolumn{6}{|c|}{ Colour of apical leaves } \\
\hline 3. Light green & 0.54 & 0.50 & 0.48 & 0.11 & 0.34 \\
\hline 5. Dark green & 0.27 & 0.20 & 0.18 & 0.30 & 0.25 \\
\hline 7. Purple green & 0.19 & 0.26 & 0.33 & 0.33 & 0.29 \\
\hline 9. Purple & 0.00 & 0.04 & 0.00 & 0.26 & 0.12 \\
\hline Total & 1.00 & 1.00 & 1.00 & 1.00 & 1.00 \\
\hline \multicolumn{6}{|c|}{ Pubescence of apical leaves } \\
\hline 0. Absent & 0.23 & 0.22 & 0.27 & 0.90 & 0.52 \\
\hline 1. Present & 0.77 & 0.78 & 0.73 & 0.10 & 0.48 \\
\hline Total & 1.00 & 1.00 & 1.00 & 1.00 & 1.00 \\
\hline \multicolumn{6}{|c|}{ Shape of central leaflet } \\
\hline 0. Ovoid & 0.00 & 0.00 & 0.00 & 0.05 & 0.02 \\
\hline 1. Elliptic-lanceolate & 0.00 & 0.63 & 0.85 & 0.44 & 0.50 \\
\hline 2. Obovate-lanceolate & 0.00 & 0.00 & 0.00 & 0.01 & 0.01 \\
\hline 3. Oblong-lanceolate & 0.00 & 0.07 & 0.00 & 0.01 & 0.03 \\
\hline 4. Lanceolate & 0.96 & 0.28 & 0.15 & 0.40 & 0.40 \\
\hline 5. Straight or linear & 0.00 & 0.00 & 0.00 & 0.04 & 0.02 \\
\hline \multicolumn{6}{|l|}{ 6. Pandurate } \\
\hline 7. Linear-piramidal & 0.04 & 0.02 & 0.00 & 0.02 & 0.02 \\
\hline 8. Linear-pandurate & 0.00 & 0.00 & 0.00 & 0.01 & 0.01 \\
\hline 9. Linear-hostatilobalate & 0.00 & 0.00 & 0.00 & 0.01 & 0.01 \\
\hline Total & 1.00 & 1.00 & 1.00 & 1.00 & 1.00 \\
\hline \multicolumn{6}{|c|}{ Petiole colour } \\
\hline 1. Yellowish green & 0.00 & 0.00 & 0.06 & 0.02 & 0.02 \\
\hline 2. Green & 0.08 & 0.09 & 0.03 & 0.04 & 0.06 \\
\hline 3. Reddish green & 0.00 & 0.07 & 0.00 & 0.00 & 0.02 \\
\hline 5. Greenish red & 0.88 & 0.61 & 0.39 & 0.16 & 0.42 \\
\hline 7. Red & 0.00 & 0.15 & 0.15 & 0.22 & 0.16 \\
\hline 9. Purple & 0.00 & 0.04 & 0.03 & 0.16 & 0.14 \\
\hline 10. Yellowish Green-red & 0.00 & 0.02 & 0.33 & 0.11 & 0.13 \\
\hline \multicolumn{6}{|l|}{ 11. Reddish yellow green } \\
\hline \multicolumn{6}{|l|}{ 12. Purplish-green } \\
\hline 13. Greenish-purple & 0.04 & 0.02 & 0.00 & 0.11 & 0.06 \\
\hline Total & 1.00 & 1.00 & 1.00 & 1.00 & 1.00 \\
\hline \multicolumn{6}{|c|}{ Leaf colour } \\
\hline 3. Light green & 0.00 & 0.02 & 0.00 & 0.09 & 0.04 \\
\hline 5. Dark green & 1.00 & 0.98 & 1.00 & 0.90 & 0.95 \\
\hline 7. Purple green & 0.00 & 0.00 & 0.00 & 0.01 & 0.01 \\
\hline \multicolumn{6}{|l|}{ 9. Purple } \\
\hline Total & 1.00 & 1.00 & 1.00 & 1.00 & 1.00 \\
\hline \multicolumn{6}{|c|}{ Colour of stem epidermis } \\
\hline 1. Greenish-yellow & 0.00 & 0.00 & 0.03 & 0.01 & 0.01 \\
\hline 2. Light green & 0.04 & 0.02 & 0.88 & 0.24 & 0.26 \\
\hline 3. Dark green & 0.92 & 0.98 & 0.03 & 0.40 & 0.57 \\
\hline \multicolumn{6}{|l|}{ 4. Purple cream } \\
\hline 5. Purple & 0.00 & 0.00 & 0.00 & 0.26 & 0.11 \\
\hline 6. Green with red purple stripes & 0.04 & 0.00 & 0.06 & 0.06 & 0.04 \\
\hline 7. Purple green & 0.00 & 0.00 & 0.00 & 0.02 & 0.01 \\
\hline Total & 1.00 & 1.00 & 1.00 & 1.00 & 1.00 \\
\hline
\end{tabular}




\begin{tabular}{|c|c|c|c|c|c|}
\hline \multicolumn{6}{|c|}{ Flowering } \\
\hline 0. Absent & 0.85 & 0.33 & 0.12 & 0.09 & 0.26 \\
\hline 1. Present & 0.15 & 0.67 & 0.88 & 0.91 & 0.74 \\
\hline Total & 1.00 & 1.00 & 1.00 & 1.00 & 1.00 \\
\hline \multicolumn{6}{|c|}{ Colour of terminal branches of adult plant } \\
\hline 2. Light green & 0.00 & 0.04 & 0.91 & 0.35 & 0.31 \\
\hline 3. Dark green & 0.96 & 0.94 & 0.03 & 0.23 & 0.49 \\
\hline 5. Purple green & 0.04 & 0.02 & 0.03 & 0.23 & 0.11 \\
\hline 6. Red green & 0.00 & 0.00 & 0.03 & 0.11 & 0.05 \\
\hline 7. Purple & 0.00 & 0.00 & 0.00 & 0.07 & 0.03 \\
\hline Total & 1.00 & 1.00 & 1.00 & 1.00 & 1.00 \\
\hline \multicolumn{6}{|c|}{ Plant earliness } \\
\hline 3. Early (3-6 months) & 0.00 & 0.02 & 0.00 & 0.02 & 0.02 \\
\hline 5. Intermediate (6-9 months) & 0.96 & 0.30 & 0.79 & 0.82 & 0.69 \\
\hline 7. Mate ( $>9$ months) & 0.04 & 0.69 & 0.21 & 0.16 & 0.30 \\
\hline Total & 1.00 & 1.00 & 1.00 & 1.00 & 1.00 \\
\hline \multicolumn{6}{|c|}{ Shape of plant } \\
\hline 1. Compact & 0.04 & 0.12 & 0.06 & 0.06 & 0.07 \\
\hline 2. Open & 0.04 & 0.02 & 0.00 & 0.01 & 0.02 \\
\hline 3. Umbrella & 0.60 & 0.62 & 0.67 & 0.56 & 0.60 \\
\hline 4. Cylindrical & 0.16 & 0.13 & 0.12 & 0.20 & 0.16 \\
\hline 5. Erect & 0.16 & 0.12 & 0.15 & 0.16 & 0.15 \\
\hline Total & 1.00 & 1.00 & 1.00 & 1.00 & 1.00 \\
\hline \multicolumn{6}{|c|}{ Root constrictions } \\
\hline 0 . Absent & 0.92 & 0.78 & 0.79 & 0.80 & 0.81 \\
\hline 1. Present & 0.08 & 0.22 & 0.21 & 0.20 & 0.19 \\
\hline Total & 1.00 & 1.00 & 1.00 & 1.00 & 1.00 \\
\hline \multicolumn{6}{|c|}{ Texture of root epidermis } \\
\hline 3. Smooth & 0.15 & 0.02 & 0.15 & 0.02 & 0.06 \\
\hline 5. Intermediate & 0.23 & 0.35 & 0.24 & 0.16 & 0.24 \\
\hline 7. Rough & 0.62 & 0.63 & 0.61 & 0.82 & 0.70 \\
\hline Total & 1.00 & 1.00 & 1.00 & 1.00 & 1.00 \\
\hline \multicolumn{6}{|c|}{ Extent of root peduncle } \\
\hline 1. Sessile & 0.42 & 0.11 & 0.39 & 0.10 & 0.19 \\
\hline 3. Short & 0.38 & 0.52 & 0.30 & 0.28 & 0.36 \\
\hline 5. Intermediate & 0.15 & 0.28 & 0.09 & 0.46 & 0.31 \\
\hline 7. Long & 0.04 & 0.09 & 0.21 & 0.16 & 0.13 \\
\hline Total & 1.00 & 1.00 & 1.00 & 1.00 & 1.00 \\
\hline \multicolumn{6}{|c|}{ Colour of root cortex } \\
\hline 1. White & 0.08 & 0.20 & 0.15 & 0.23 & 0.19 \\
\hline 2. Cream & 0.08 & 0.22 & 0.18 & 0.22 & 0.19 \\
\hline 3. Yellow & 0.08 & 0.06 & 0.03 & 0.07 & 0.06 \\
\hline 4. Pink & 0.19 & 0.15 & 0.45 & 0.04 & 0.16 \\
\hline 5. Purple & 0.58 & 0.37 & 0.18 & 0.44 & 0.39 \\
\hline Total & 1.00 & 1.00 & 1.00 & 1.00 & 1.00 \\
\hline \multicolumn{6}{|c|}{ Colour of root pulp } \\
\hline 1. White & 0.96 & 0.85 & 0.91 & 0.73 & 0.83 \\
\hline 2. Cream & 0.00 & 0.13 & 0.09 & 0.18 & 0.13 \\
\hline 3. Yellow & 0.04 & 0.02 & 0.00 & 0.09 & 0.05 \\
\hline \multicolumn{6}{|l|}{ 4. Orange } \\
\hline \multicolumn{6}{|l|}{ 5. Pink } \\
\hline Total & 1.00 & 1.00 & 1.00 & 1.00 & 1.00 \\
\hline \multicolumn{6}{|c|}{ Shape of root } \\
\hline 1. Conical & 0.23 & 0.28 & 0.12 & 0.16 & 0.19 \\
\hline 2. Conical-cylindrical & 0.73 & 0.63 & 0.82 & 0.63 & 0.68 \\
\hline 3. Cylindrical & 0.04 & 0.07 & 0.03 & 0.20 & 0.11 \\
\hline 4. Irregular & 0.00 & 0.02 & 0.03 & 0.01 & 0.02 \\
\hline Total & 1.00 & 1.00 & 1.00 & 1.00 & 1.00 \\
\hline \multicolumn{6}{|c|}{ Cortex: ease of peeling } \\
\hline 1. Easy & 0.92 & 0.80 & 0.97 & 0.88 & 0.88 \\
\hline 2. Difficult & 0.08 & 0.20 & 0.03 & 0.12 & 0.12 \\
\hline Total & 1.00 & 1.00 & 1.00 & 1.00 & 1.00 \\
\hline
\end{tabular}


Appendix 4. Ecogeographic variability with quantitative characters based on the three groups obtained through multivariate analysis for the Ecuadorian cassava collection.

\begin{tabular}{|c|c|c|c|c|c|c|c|c|c|c|c|c|c|c|c|c|c|c|}
\hline \multirow{2}{*}{ Variables } & \multicolumn{6}{|c|}{ Group 1} & \multicolumn{6}{|c|}{ Group 2} & \multicolumn{6}{|c|}{ Group 3} \\
\hline & $\mathbf{n}$ & Mean & SD & $\mathrm{CV}$ & Min & Max & $\mathbf{n}$ & Mean & SD & $\mathrm{CV}$ & Min & Max & $\mathbf{n}$ & Mean & SD & CV & Min & Max \\
\hline Altitude, $\mathrm{m}$ a.s.l. & 19 & 347 & 0 & 0 & 347 & 347 & 94 & 165.62 & 108.8 & 65.67 & 5 & 438 & 81 & 591 & 286.3 & 48.43 & 255 & 1566 \\
\hline Annual average temperature, ${ }^{\circ} \mathrm{C}$ & 19 & 23.5 & 0 & 0 & 23.5 & 23.5 & 95 & 24.84 & 0.59 & 2.39 & 23.5 & 26 & 81 & 23.22 & 1.3 & 5.6 & 18.4 & 24.9 \\
\hline Isothermality*, ${ }^{\circ} \mathrm{C}$ & 19 & 8.3 & 0 & 0 & 8.3 & 8.3 & 95 & 8.03 & 0.31 & 3.82 & 7 & 8.8 & 81 & 8.66 & 0.22 & 2.59 & 8 & 9 \\
\hline Temperature seasonality**, ${ }^{\circ} \mathrm{C}$ & 19 & 63.5 & 0 & 0 & 63.5 & 63.5 & 95 & 67.81 & 10.85 & 16 & 36.5 & 92.6 & 81 & 43.06 & 7.36 & 17.1 & 31.7 & 66.3 \\
\hline Maximum temperature, warmest month, ${ }^{\circ} \mathrm{C}$ & 19 & 29.2 & 0 & 0 & 29.2 & 29.2 & 95 & 30.77 & 0.72 & 2.35 & 29.2 & 31.9 & 81 & 29.09 & 1.31 & 4.51 & 24.1 & 30.7 \\
\hline Minimum temperature, coldest month, ${ }^{\circ} \mathrm{C}$ & 19 & 17.4 & 0 & 0 & 17.4 & 17.4 & 95 & 19.07 & 0.63 & 3.3 & 17.9 & 21.8 & 81 & 17.73 & 1.39 & 7.82 & 12.9 & 19.5 \\
\hline Annual temperature range****, ${ }^{\circ} \mathrm{C}$ & 19 & 11.8 & 0 & 0 & 11.8 & 11.8 & 95 & 11.71 & 0.82 & 7 & 7.8 & 12.7 & 81 & 11.36 & 0.58 & 5.15 & 10.9 & 13.6 \\
\hline $\begin{array}{l}\text { Average temperature, coldest quarter ( } 3 \\
\text { coldest months), }{ }^{\circ} \mathrm{C}\end{array}$ & 19 & 22.7 & 0 & 0 & 22.7 & 22.7 & 95 & 24.02 & 0.59 & 2.45 & 22.6 & 25.6 & 81 & 22.57 & 1.35 & 6 & 17.6 & 24.3 \\
\hline $\begin{array}{l}\text { Average temperature for the quarter with } \\
\text { most rainfall ( } 3 \text { rainiest months), }{ }^{\circ} \mathrm{C}\end{array}$ & 19 & 24.3 & 0 & 0 & 24.3 & 24.3 & 95 & 25.51 & 0.61 & 2.41 & 24.2 & 26.5 & 81 & 22.93 & 1.23 & 5.37 & 18.3 & 24.5 \\
\hline $\begin{array}{l}\text { Average temperature for the hottest quarter } \\
\text { ( } 3 \text { hottest months), }{ }^{\circ} \mathrm{C}\end{array}$ & 19 & 24.3 & 0 & 0 & 24.3 & 24.3 & 95 & 25.69 & 0.55 & 2.13 & 24.5 & 26.5 & 81 & 23.68 & 1.32 & 5.59 & 18.7 & 25.4 \\
\hline Maximum temperature for January, ${ }^{\circ} \mathrm{C}$ & 19 & 28.5 & 0 & 0 & 28.5 & 28.5 & 95 & 29.87 & 0.75 & 2.5 & 28.2 & 31 & 81 & 28.29 & 1.46 & 5.15 & 23 & 30.1 \\
\hline Maximum temperature for February, ${ }^{\circ} \mathrm{C}$ & 19 & 28.5 & 0 & 0 & 28.5 & 28.5 & 95 & 30.02 & 0.64 & 2.14 & 28.5 & 31.2 & 81 & 28.37 & 1.39 & 4.89 & 23.1 & 30.5 \\
\hline Maximum temperature for March, ${ }^{\circ} \mathrm{C}$ & 19 & 29 & 0 & 0 & 29 & 29 & 95 & 30.49 & 0.72 & 2.37 & 28.8 & 31.5 & 81 & 28.18 & 1.32 & 4.68 & 23.2 & 29.9 \\
\hline Maximum temperature for April, ${ }^{\circ} \mathrm{C}$ & 19 & 29.2 & 0 & 0 & 29.2 & 29.2 & 95 & 30.68 & 0.83 & 2.71 & 29.1 & 31.9 & 81 & 28.04 & 1.19 & 4.24 & 23.3 & 29.6 \\
\hline Maximum temperature for May, ${ }^{\circ} \mathrm{C}$ & 19 & 28.5 & 0 & 0 & 28.5 & 28.5 & 95 & 29.87 & 0.79 & 2.64 & 28.2 & 31 & 81 & 27.7 & 1.16 & 4.19 & 23.1 & 29.4 \\
\hline Maximum temperature for June, ${ }^{\circ} \mathrm{C}$ & 19 & 27.4 & 0 & 0 & 27.4 & 27.4 & 95 & 28.72 & 0.72 & 2.5 & 27 & 30.1 & 81 & 27.19 & 1.27 & 4.67 & 22.4 & 28.8 \\
\hline Maximum temperature for July, ${ }^{\circ} \mathrm{C}$ & 19 & 27.3 & 0 & 0 & 27.3 & 27.3 & 95 & 28.49 & 0.74 & 2.58 & 26.8 & 29.9 & 81 & 27 & 1.35 & 5.01 & 21.9 & 28.5 \\
\hline Minimum temperature for January, ${ }^{\circ} \mathrm{C}$ & 19 & 19.4 & 0 & 0 & 19.4 & 19.4 & 95 & 20.7 & 0.59 & 2.83 & 19.6 & 22.6 & 81 & 18.4 & 1.29 & 7 & 14 & 20.1 \\
\hline Minimum temperature for February, ${ }^{\circ} \mathrm{C}$ & 19 & 19.7 & 0 & 0 & 19.7 & 19.7 & 95 & 20.83 & 0.68 & 3.25 & 19.6 & 22.8 & 81 & 18.39 & 1.31 & 7.14 & 14.1 & 20.2 \\
\hline Minimum temperature for March, ${ }^{\circ} \mathrm{C}$ & 19 & 20 & 0 & 0 & 20 & 20 & 95 & 21.17 & 0.61 & 2.89 & 19.9 & 22.9 & 81 & 18.49 & 1.32 & 7.14 & 14.2 & 20.3 \\
\hline Minimum temperature for April, ${ }^{\circ} \mathrm{C}$ & 19 & 19.7 & 0 & 0 & 19.7 & 19.7 & 95 & 21.06 & 0.57 & 2.72 & 19.9 & 23 & 81 & 18.49 & 1.29 & 6.96 & 14.2 & 20.4 \\
\hline Minimum temperature for May, ${ }^{\circ} \mathrm{C}$ & 19 & 19.2 & 0 & 0 & 19.2 & 19.2 & 95 & 20.67 & 0.67 & 3.24 & 19.5 & 23 & 81 & 18.49 & 1.22 & 6.59 & 14.1 & 20.2 \\
\hline Minimum temperature for June, ${ }^{\circ} \mathrm{C}$ & 19 & 18.5 & 0 & 0 & 18.5 & 18.5 & 95 & 20.08 & 0.62 & 3.1 & 19 & 22.5 & 81 & 18.12 & 1.38 & 7.59 & 13.3 & 20 \\
\hline Minimum temperature for July, ${ }^{\circ} \mathrm{C}$ & 19 & 17.8 & 0 & 0 & 17.8 & 17.8 & 95 & 19.45 & 0.62 & 3.17 & 18.4 & 22.2 & 81 & 17.81 & 1.39 & 7.83 & 13 & 19.7 \\
\hline Minimum temperature for August, ${ }^{\circ} \mathrm{C}$ & 19 & 17.4 & 0 & 0 & 17.4 & 17.4 & 95 & 19.07 & 0.64 & 3.38 & 17.9 & 22.1 & 81 & 17.73 & 1.39 & 7.83 & 12.9 & 19.5 \\
\hline Minimum temperature for September, ${ }^{\circ} \mathrm{C}$ & 19 & 17.5 & 0 & 0 & 17.5 & 17.5 & 95 & 19.23 & 0.58 & 3.02 & 18 & 21.8 & 81 & 18.17 & 1.37 & 7.56 & 13.1 & 19.9 \\
\hline Minimum temperature for October, ${ }^{\circ} \mathrm{C}$ & 19 & 17.7 & 0 & 0 & 17.7 & 17.7 & 95 & 19.59 & 0.59 & 3.02 & 18.3 & 22 & 81 & 18.41 & 1.33 & 7.24 & 13.6 & 20.1 \\
\hline Minimum temperature for December, ${ }^{\circ} \mathrm{C}$ & 19 & 18.6 & 0 & 0 & 18.6 & 18.6 & 95 & 20.09 & 0.54 & 2.67 & 19 & 22.3 & 81 & 18.58 & 1.3 & 6.97 & 13.8 & 20.5 \\
\hline Average temperature for January, ${ }^{\circ} \mathrm{C}$ & 19 & 23.9 & 0 & 0 & 23.9 & 23.9 & 95 & 25.25 & 0.56 & 2.24 & 23.9 & 26.2 & 81 & 23.32 & 1.35 & 5.81 & 18.5 & 25.1 \\
\hline Average temperature for February, ${ }^{\circ} \mathrm{C}$ & 19 & 24.1 & 0 & 0 & 24.1 & 24.1 & 95 & 25.39 & 0.57 & 2.23 & 24.2 & 26.3 & 81 & 23.35 & 1.32 & 5.66 & 18.6 & 25.3 \\
\hline Average temperature for March, ${ }^{\circ} \mathrm{C}$ & 19 & 24.5 & 0 & 0 & 24.5 & 24.5 & 95 & 25.81 & 0.59 & 2.3 & 24.6 & 26.6 & 81 & 23.31 & 1.31 & 5.62 & 18.7 & 25 \\
\hline Average temperature for April, ${ }^{\circ} \mathrm{C}$ & 19 & 24.4 & 0 & 0 & 24.4 & 24.4 & 95 & 25.85 & 0.64 & 2.47 & 24.5 & 26.8 & 81 & 23.23 & 1.2 & 5. & 18.7 & 24.9 \\
\hline Average temperature for May, ${ }^{\circ} \mathrm{C}$ & 19 & 23.8 & 0 & 0 & 23.8 & 23.8 & 95 & 25.24 & 0.65 & 2.56 & 24 & 26.4 & 81 & 23.07 & 1.18 & 5.11 & 18.6 & 24.8 \\
\hline Average temperature for June, ${ }^{\circ} \mathrm{C}$ & 19 & 22.9 & 0 & 0 & 22.9 & 22.9 & 95 & 24.37 & 0.57 & 2.34 & 23.2 & 26 & 81 & 22.62 & 1.32 & 5.85 & 17.8 & 24.4 \\
\hline Average temperature for July, ${ }^{\circ} \mathrm{C}$ & 19 & 22.5 & 0 & 0 & 22.5 & 22.5 & 95 & 23.95 & 0.56 & 2.33 & 22.6 & 25.7 & 81 & 22.38 & 1.36 & 6.1 & 17.4 & 24.1 \\
\hline Average temperature for August, ${ }^{\circ} \mathrm{C}$ & 19 & 22.8 & 0 & 0 & 22.8 & 22.8 & 95 & 24.03 & 0.6 & 2.49 & 22.5 & 25.7 & 81 & 22.82 & 1.37 & 5.99 & 17.8 & 24.6 \\
\hline Average temperature for October, ${ }^{\circ} \mathrm{C}$ & 19 & 23.1 & 0 & 0 & 23.1 & 23.1 & 95 & 24.45 & 0.69 & 2.84 & 22.8 & 25.8 & 81 & 23.62 & 1.33 & 5.62 & 18.6 & 25.3 \\
\hline Average temperature for December, ${ }^{\circ} \mathrm{C}$ & 19 & 23.8 & 0 & 0 & 23.8 & 23.8 & 95 & 24.92 & 0.72 & 2.9 & 23.1 & 26.1 & 81 & 23.73 & 1.34 & 5.64 & 18.7 & 25.6 \\
\hline $\begin{array}{l}\text { Rainfall during the hottest quarter ( } 3 \text { hottest } \\
\text { months), mm }\end{array}$ & 19 & 845 & 0 & 0 & 845 & 845 & 95 & 784.69 & 441.20 & 56.23 & 193 & 1615 & 81 & 30.6 & 177.7 & 21.39 & 420 & 1074 \\
\hline Average rainfall for May, $\mathrm{mm}$ & 19 & 117 & 0 & 0 & 117 & 117 & 95 & 124.28 & & 87.68 & 9 & 329 & 81 & 356.5 & 75.75 & 21.25 & 183 & 470 \\
\hline Average rainfall for August, $\mathrm{mm}$ & 19 & 8 & 0 & 0 & 8 & 8 & 95 & 29.47 & 50.14 & 170.1 & 2 & 208 & 81 & 237.2 & 54.42 & 22.94 & 118 & 349 \\
\hline Average rainfall for October, $\mathrm{mm}$ & 19 & 9 & 0 & 0 & 9 & 9 & 95 & 43.56 & 79.81 & 183.2 & 3 & 310 & 81 & 294.7 & 61.23 & 20.77 & 149 & 367 \\
\hline Sand content of soil, \% & 19 & 30 & 0 & 0 & 30 & 30 & 94 & 29.2 & 10.6 & 36.29 & 23 & 72 & 81 & 33.21 & 16.16 & 48.66 & 11 & 58 \\
\hline Sand content of subsoil, $\%$ & 19 & 20 & 0 & 0 & 20 & 20 & 94 & 23.97 & 11.214 & $4 \quad 6.77$ & 18 & 70 & 79 & 33.33 & 16.29 & 48.87 & 13 & 64 \\
\hline Gravel content of subsoil, $\%$ & 19 & 1 & 0 & 0 & 1 & 1 & 94 & 1.5 & 1.82 & 121.2 & 0 & 4 & 79 & 12.63 & 18.49 & 146.4 & 0 & 49 \\
\hline
\end{tabular}


Appendix 5. Ecogeographic variation of qualitative characters based on the grouping of dendrograms for the Ecuadorian cassava collection.

\begin{tabular}{|c|c|c|c|c|}
\hline & Group & Group & Group & Total \\
\hline \multicolumn{5}{|c|}{ Slope } \\
\hline 1. Flat $\left(0-2^{\circ}\right)$ & 1 & 0.78 & 0.81 & 0.81 \\
\hline 2. Very smooth $\left(2-5^{\circ}\right)$ & 0 & 0.22 & 0.14 & 0.16 \\
\hline 3. Smooth $\left(5-12^{\circ}\right)$ & 0 & 0 & 0.05 & 0.02 \\
\hline Total & 1 & 1 & 1 & 1 \\
\hline \multicolumn{5}{|c|}{ Total exchangeable bases in surface soil } \\
\hline 1. Low fertility & 0 & 0.24 & 0.53 & 0.34 \\
\hline 2. Medium fertility & 0 & 0.04 & 0.47 & 0.22 \\
\hline 3. High fertility & 1 & 0.71 & 0 & 0.44 \\
\hline Total & 1 & 1 & 1 & 1 \\
\hline \multicolumn{5}{|c|}{ Organic carbon content in surface soil } \\
\hline 1. Very low & 0 & 0.23 & 0 & 0.11 \\
\hline 2. Low & 0 & 0.54 & 0.89 & 0.63 \\
\hline 3. Medium & 1 & 0.22 & 0 & 0.21 \\
\hline 4. High & 0 & 0 & 0.11 & 0.05 \\
\hline Total & 1 & 1 & l & 1 \\
\hline \multicolumn{5}{|c|}{ Cation exchange capacity in surface soil } \\
\hline 1. Very low & 0 & 0.07 & 0.02 & 0.05 \\
\hline 2. Low & 0 & 0.19 & 0.98 & 0.5 \\
\hline 3. Medium & 1 & 0.73 & 0 & 0.45 \\
\hline \multicolumn{5}{|c|}{ Clay cation exchange capacity in surface } \\
\hline 2. Low & 0 & 0 & 0.35 & 0.14 \\
\hline 3. Medium & 0 & 0.12 & 0.44 & 0.23 \\
\hline 4. High & 0 & 0 & 0.21 & 0.08 \\
\hline 5. Very high & 1 & 0.88 & 0 & 0.55 \\
\hline Total & 1 & 1 & 1 & l \\
\hline \multicolumn{5}{|c|}{ Apparent bulk density reference in surface soi } \\
\hline 1. Peaty horizons & 0 & 0 & 0.28 & 0.12 \\
\hline 2. Volcanic soil horizons & 0 & 0.93 & 0.57 & 0.69 \\
\hline $\begin{array}{l}\text { 3. Clay horizons with } \\
\text { structure }\end{array}$ & 1 & 0.07 & 0.15 & 0.2 \\
\hline Total & 1 & 1 & 1 & 1 \\
\hline \multicolumn{5}{|c|}{ Apparent bulk density reference in subsoil } \\
\hline 1. Peaty horizons & 0 & 0 & 0.29 & 0.12 \\
\hline 2. Volcanic soil horizons & 1 & 0.96 & 0.59 & 0.81 \\
\hline $\begin{array}{l}\text { 3. Clay horizons with } \\
\text { structure }\end{array}$ & 0 & 0.04 & 0.11 & 0.07 \\
\hline lotal & 1 & 1 & 1 & 1 \\
\hline \multicolumn{5}{|c|}{ Surface soil pH in a soil-water solution } \\
\hline 1. Very acid & 0 & 0.01 & 0.49 & 0.21 \\
\hline 2. Acid & 0 & 0.27 & 0.41 & 0.3 \\
\hline 3. Moderately acid, & 0 & 0.16 & 0.1 & 0.12 \\
\hline 4. Slightly acid & 1 & 0.51 & 0 & 0.34 \\
\hline 5. Practically neutral & 0 & 0.01 & 0 & 0.01 \\
\hline 6. Neutral & 0 & 0.04 & 0 & 0.02 \\
\hline Total & 1 & 1 & 1 & 1 \\
\hline \multicolumn{5}{|c|}{ pH in subsoil in soil-water solution } \\
\hline 1. Very acid & 0 & 0.01 & 0.49 & 0.21 \\
\hline 2. Acid & 0 & 0.28 & 0.39 & 0.3 \\
\hline 3. Moderately acid, & () & 0.04 & 0.01 & 0.03 \\
\hline 4. Slightly acid & 1 & 0.62 & 0.1 & 0.44 \\
\hline 5. Practically neutral & 0 & 0.01 & 0 & 0.01 \\
\hline 6. Neutral & () & 0.04 & 0 & 0.02 \\
\hline Total & 1 & 1 & 1 & 1 \\
\hline \multicolumn{5}{|c|}{ Saturation of bases in surface soil } \\
\hline 1. Very acidic soil & 0 & 0.21 & 1 & 0.52 \\
\hline 2. Medium soil & 1 & 0.22 & 0 & 0.21 \\
\hline 3. Soil saturated in bases & 0 & 0.56 & 0 & 0.27 \\
\hline Total & 1 & 1 & l & 1 \\
\hline
\end{tabular}


Supplementary Table 1. Thematic layers used in the ecogeographic characterization in cassava collection.

\begin{tabular}{|c|c|c|}
\hline Variable & Unit/category & Component* \\
\hline Annual average temperature & ${ }^{\circ} \mathrm{C}$ & Bioclimatic \\
\hline Isothermality & ${ }^{\circ} \mathrm{C}$ & Bioclimatic \\
\hline Temperature seasonality & ${ }^{\circ} \mathrm{C}$ & Bioclimatic \\
\hline Maximum temperature for the warmest month & ${ }^{\circ} \mathrm{C}$ & Bioclimatic \\
\hline Minimum temperature for the coldest month & ${ }^{\circ} \mathrm{C}$ & Bioclimatic \\
\hline Annual temperature range & ${ }^{\circ} \mathrm{C}$ & Bioclimatic \\
\hline $\begin{array}{l}\text { Average temperature for the coldest quarter ( } 3 \\
\text { coldest months) }\end{array}$ & ${ }^{\circ} \mathrm{C}$ & Bioclimatic \\
\hline $\begin{array}{l}\text { Average temperature for the quarter with most } \\
\text { rainfall ( } 3 \text { rainiest months) }\end{array}$ & ${ }^{\circ} \mathrm{C}$ & Bioclimatic \\
\hline $\begin{array}{l}\text { Average temperature for the hottest quarter ( } 3 \\
\text { hottest months) }\end{array}$ & ${ }^{\circ} \mathrm{C}$ & Bioclimatic \\
\hline Maximum temperature for January & ${ }^{\circ} \mathrm{C}$ & Bioclimatic \\
\hline Maximum temperature for February & ${ }^{\circ} \mathrm{C}$ & Bioclimatic \\
\hline Maximum temperature for March & ${ }^{\circ} \mathrm{C}$ & Bioclimatic \\
\hline Maximum temperature for April & ${ }^{\circ} \mathrm{C}$ & Bioclimatic \\
\hline Maximum temperature for May & ${ }^{\circ} \mathrm{C}$ & Bioclimatic \\
\hline Maximum temperature for June & ${ }^{\circ} \mathrm{C}$ & Bioclimatic \\
\hline Maximum temperature for July & ${ }^{\circ} \mathrm{C}$ & Bioclimatic \\
\hline Minimum temperature for January & ${ }^{\circ} \mathrm{C}$ & Bioclimatic \\
\hline Minimum temperature for February & ${ }^{\circ} \mathrm{C}$ & Bioclimatic \\
\hline Minimum temperature for March & ${ }^{\circ} \mathrm{C}$ & Bioclimatic \\
\hline Minimum temperature for April & ${ }^{\circ} \mathrm{C}$ & Bioclimatic \\
\hline Minimum temperature for May & ${ }^{\circ} \mathrm{C}$ & Bioclimatic \\
\hline Minimum temperature for June & ${ }^{\circ} \mathrm{C}$ & Bioclimatic \\
\hline Minimum temperature for July & ${ }^{\circ} \mathrm{C}$ & Bioclimatic \\
\hline Minimum temperature for August & ${ }^{\circ} \mathrm{C}$ & Bioclimatic \\
\hline Minimum temperature for September & ${ }^{\circ} \mathrm{C}$ & Bioclimatic \\
\hline Minimum temperature for October & ${ }^{\circ} \mathrm{C}$ & Bioclimatic \\
\hline Minimum temperature for December & ${ }^{\circ} \mathrm{C}$ & Bioclimatic \\
\hline Average temperature for January & ${ }^{\circ} \mathrm{C}$ & Bioclimatic \\
\hline Average temperature for February & ${ }^{\circ} \mathrm{C}$ & Bioclimatic \\
\hline Average temperature for March & ${ }^{\circ} \mathrm{C}$ & Bioclimatic \\
\hline Average temperature for April & ${ }^{\circ} \mathrm{C}$ & Bioclimatic \\
\hline Average temperature for May & ${ }^{\circ} \mathrm{C}$ & Bioclimatic \\
\hline Average temperature for June & ${ }^{\circ} \mathrm{C}$ & Bioclimatic \\
\hline Average temperature for July & ${ }^{\circ} \mathrm{C}$ & Bioclimatic \\
\hline Average temperature for August & ${ }^{\circ} \mathrm{C}$ & Bioclimatic \\
\hline Average temperature for October & ${ }^{\circ} \mathrm{C}$ & Bioclimatic \\
\hline
\end{tabular}


Average temperature for December ${ }^{\circ} \mathrm{C} \quad$ Bioclimatic

Rainfall during the hottest quarter (3 hottest months)

Average rainfall for May

$\mathrm{mm}$

Bioclimatic

Average rainfall for August

$\mathrm{mm}$

Bioclimatic

Average rainfall for October

$\mathrm{mm}$

Bioclimatic

Elevation

$\mathrm{mm}$

Bioclimatic

$\mathrm{m}$

Geophysical

Slope

1 Flat $\left(0-2^{\circ}\right)$, Very smooth $\left(2-5^{\circ}\right)$, Smooth $\left(5-12^{\circ}\right)$

Geophysical

1 Very acid, 2 Acid, 3

Surface soil $\mathrm{pH}$ in a soil-water solution

Moderately acid, 4 Slightly

acid, 5 Practically neutral, 6

Edaphic

Neutral

$\mathrm{pH}$ in subsoil in soil-water solution

1 Very acid, 2 Acid, 3

Moderately acid, 4 Slightly

acid, 5 Practically neutral, 6

Edaphic

Neutral

Organic carbon content in surface soil

1 Very low, 2 Low, 3

Medium, 4 High

1 Low fertility, 2 Medium

Total exchangeable bases in surface soil

Cation exchange capacity in surface soil fertility, 3 High fertility

1 Very low, 2 Low, 3 Medium

1 Very low, 2 Low, 3

Medium, 4 High, 5 Very high

1 Peaty horizons, 2 Volcanic

Apparent bulk density reference in surface soil

soil horizons, 3 Clay

horizons with structure

1 Peaty horizons, 2 Volcanic

Apparent bulk density reference in subsoil soil horizons, 3 Clay horizons with structure

1 Very acidic soil, 2 Medium

Saturation of bases in surface soil

soil, 3 Soil saturated in bases

Edaphic

Edaphic

Edaphic

Edaphic

Edaphic

Sand content of soil,

$\begin{array}{ll}\% & \text { Edaphic } \\ \% & \text { Edaphic } \\ \% & \text { Edaphic }\end{array}$

Sand content of subsoil

$\%$

Edaphic

Gravel content of subsoil

Edaphic

Edaphic

*Source for bioclimatic: WorldClim, http://www.worldclim.org, for geophysical: Shuttle Radar Mission, http://srtm.csi.cgiar.org, for edaphic: MAGAP, http://geoportal.magap.gob.ec/geonetwork/srv/spa/main.home 